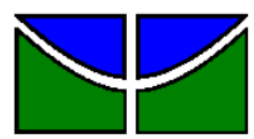

Universidade de Brasília

Faculdade de Economia, Administração e Contabilidade

Departamento de Administração

Curso de Graduação em Administração à distância

NEUSA KIYOTSUKA GOMES

\title{
ATUAÇÃO DO INSTITUTO BRASILEIRO DO MEIO \\ AMBIENTE - IBAMA EM RELAÇÃO À POLUIÇÃO DO \\ LAGO DE SERRA DA MESA NA REGIÃO DE URUAÇU/GO.
}

Brasília - DF 


\section{NEUSA KIYOTSUKA GOMES}

\section{ATUAÇÃO DO INSTITUTO BRASILEIRO DO MEIO AMBIENTE - IBAMA, EM RELAÇÃO À POLUIÇÃO DO LAGO DE SERRA DA MESA NA REGIÃO DE URUAÇU/GO.}

Monografia apresentada a Universidade de Brasília (UnB) como requisito parcial para obtenção do grau de Bacharel em Administração.

Professora Orientadora: Msc. Mariana Marlière Létti

$$
\text { Brasília - DF }
$$


Reprodução parcial permitida, desde que citada à fonte.

GOMES, Neusa Kiyotsuka.

Responsabilidade e Desempenho do Instituto Brasileiro do Meio Ambiente IBAMA em Relação à Poluição do Lago Serra da Mesa na Região de Uruaçu/GO / Neusa Kiyotsuka Gomes - Brasília, 2011.

$85 \mathrm{f}$.

Monografia (bacharelado) - Universidade de Brasília, Departamento de Administração - EAD, 2011.

Orientador: Prof. Msc. Mariana Marlière Létti, Departamento de Administração.

1. Degradação Ambiental. 2. Responsabilidade social corporativa. 3. Fiscalização ambiental. 4. Administração pública.

CDU: 


\section{ATUAÇÃO DO INSTITUTO BRASILEIRO DO MEIO AMBIENTE - IBAMA, EM RELAÇÃO À POLUIÇÃO DO LAGO DE SERRA DA MESA NA REGIÃO DE URUAÇU/GO.}

A Comissão Examinadora, abaixo identificada, aprova o Trabalho de Conclusão do Curso de Administração da Universidade de Brasília da aluna

\section{NEUSA KIYOTSUKA GOMES}

Msc. Mariana Marlière Létti

Professora-Orientadora

Msc. Marizângela Aparecida de Bortolo Pinto

Professora-Examinadora 
Dedico ao meu pai José da Conceição Gomes (in memórian), pelo apoio e por sempre estar presente em todos os momentos de minha vida. 


\section{AGRADECIMENTOS}

Aos professores com os quais tive a honra de compartilhar um pouco dos seus conhecimentos. A todos aqueles que de alguma forma contribuíram para a realização deste trabalho.

Meus sinceros agradecimentos 
"Toda empresa precisa de gente que erra, que não tem medo de errar e que aprenda com o erro."

\section{Bill Gates}




\section{RESUMO}

O presente Trabalho de Conclusão de Curso visou avaliar a atuação do Instituto Brasileiro do Meio Ambiente e dos Recursos Naturais Renováveis (IBAMA), como principal órgão de controle e fiscalização ambiental, verificando quais medidas vem sendo aplicadas pelo órgão em relação à poluição do Lago Serra da Mesa na região de Uruaçu/GO. Enfatizando-se que as funções sociais do órgão estão dentro do contexto responsabilidade social corporativa na administração pública. Em busca de respostas para a questão foi realizado um estudo, no qual inicialmente procurou-se constatar a poluição das águas do referido reservatório, e, em continuidade, foram abordadas questões relativas à atuação do órgão, tais como: a responsabilidade pelo licenciamento ambiental da Usina Hidrelétrica Serra da Mesa; dos mecanismos institucionais de controle e supervisão dos impactos ambientais ocorridos na área de pesquisa, principalmente os provocados pela ação humana na região de Uruaçu/GO; e, a ocorrência de ações de fiscalização e educação ambiental aplicadas atualmente pelo órgão no município. A pesquisa alcançou seus resultados do ponto de vista de que os pressupostos foram confirmados, demonstrando que a atuação do órgão regional de Uruaçu/GO não satisfaz plenamente as necessidades locais. A cidade possui características específicas em razão de sua proximidade ao Lago Serra da Mesa e por essa razão carece de uma fiscalização mais efetiva. O estudo propiciou o levantamento de duas observações como prováveis causas do problema, primeiro pelo fato do planejamento das operações de fiscalização serem apenas no âmbito da administração pública federal, o que poderá limitar as ações individuais dos órgãos municipais, e, segundo pelo reduzido efetivo de fiscais do município. Evidencia-se a necessidade de um melhor desempenho nas ações de fiscalização do órgão municipal como meio de monitoramento e controle dos problemas ambientais da região.

Palavras chave: Degradação Ambiental; Responsabilidade social e corporativa; Fiscalização ambiental; Administração pública. 


\section{SUMÁRIO}

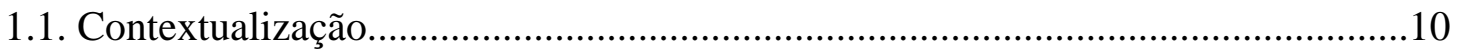

1.2. Formulação do Problema..................................................................................12

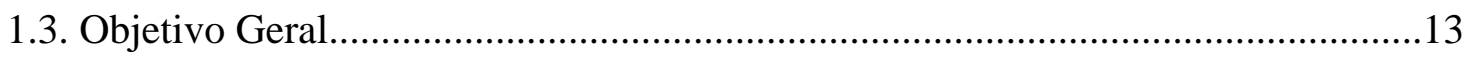

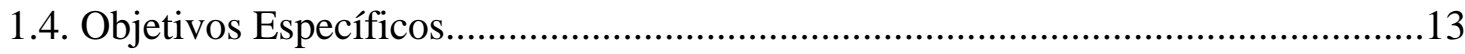

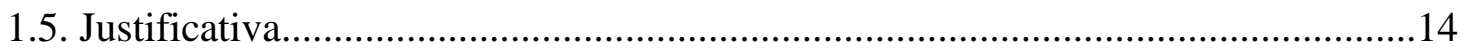

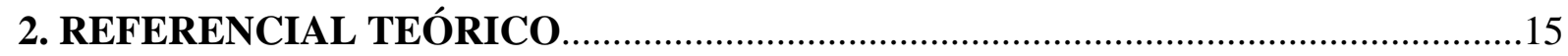

2.1. A Questão Ambiental e Responsabilidade Social Corporativa...............................15

2.2. Instrumentos de Políticas Ambientais Existentes e Suas Aplicações......................16

2.3. Principais Causas e Conseqüências da Poluição do Lago de Serra da Mesa.........19

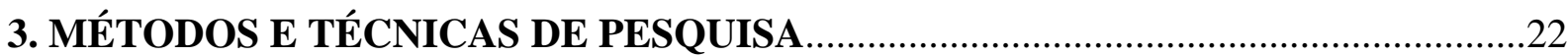

3.1. Tipo e Descrição Geral da Pesquisa................................................................22

3.2. Caracterização da Organização, Setor ou Área do Objeto de Estudo.....................22

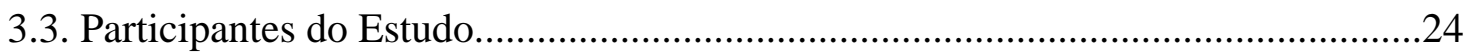

3.4. Caracterização dos Instrumentos de Pesquisa.........................................................25

3.5. Procedimentos de Coleta e de Análise de Dados...................................................26

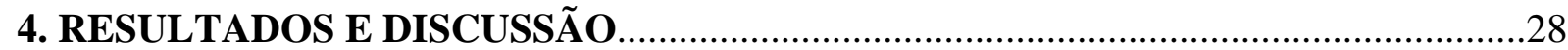

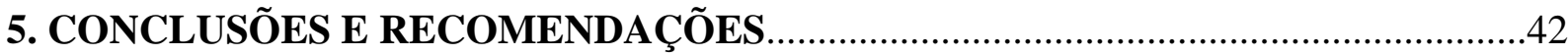

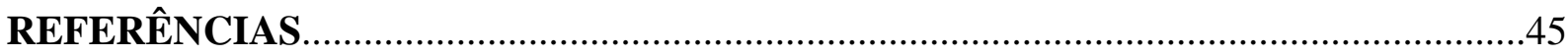




\section{APÊNDICES}

Apêndice A - Carta de Apresentação..........................................................................47

Apêndice B - Termo de Consentimento Informado....................................................48

Apêndice C - Pesquisa de Campo - $1^{\mathrm{a}}$ etapa...........................................................49

Apêndice D - Pesquisa de Campo - 2 ${ }^{\mathrm{a}}$ etapa...............................................................53

Apêndice E - Pesquisa de Campo - 3 ${ }^{\mathrm{a}}$ etapa.................................................................56

\section{ANEXOS}

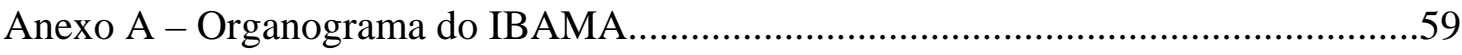

Anexo B - Nota Técnica n ${ }^{\circ}$ 10/2010-COLIC/DGPA/IBAMA-GO................................60

Anexo C - Parecer Técnico nº 20/2010-COLIC/DGPA/IBAMA-GO...........................66

Anexo D - Autos de Infrações Lavrados no ano 2009...................................................83

Anexo E - Autos de Infrações Lavrados no Ano 2010 .................................................85 


\section{INTRODUÇÃO}

\subsection{Contextualização}

Atualmente, a poluição das águas tem sido tema bastante debatido em todo o mundo, e cada vez mais tem se buscado soluções para os problemas relacionados à falta de preservação dos recursos hídricos. Embora venha aumentando a conscientização de que esse recurso pode acabar e medidas de preservação estejam sendo tomadas em diversas esferas, a título de exemplo cito, a proposta apresentada pela organização não-governamental Greenpeace, em 1990, da "Produção Limpa”. Explicada por Nascimento (2008, p. 111), essa proposta representa um sistema de produção industrial que leve em conta a sustentabilidade de fontes renováveis de matérias-primas, resultando, por exemplo, na redução do consumo de água e energia. Outro exemplo dessa conscientização pode ser demonstrado na oficialização do dia 22 de março como o Dia Mundial da Água, pela Organização das Nações Unidas, no ano de 2003. A data tem o objetivo de chamar a atenção sobre os problemas relacionados ao consumo de água potável no mundo.

De acordo com Nascimento (2008, p. 155), “[...] 97,5\% da água do Planeta é salgada, [...]. A água doce corresponde a 2,5\%, sendo que 2,493\% estão em geleiras ou aqüíferos, de difícil acesso e, apenas 0,007\% está disponível em rios, lagos e na atmosfera [...]”. Diante a escassez deste recurso é preocupante os descasos como os observados na região de UruaçuGO.

Com a implantação da UHE Serra da Mesa, a cidade passou a ser freqüentada por turistas de várias localidades, em especial Brasília e Goiânia, que buscam o reservatório para lazer, e principalmente para pesca. Como parte da cidade da acesso ao lago foi criada às suas margens uma praia artificial, no local há diversos restaurantes e bares feitos em flutuantes na água, onde são depositados dejetos do esgoto desses estabelecimentos, além de todo tipo de lixo produzido pelos visitantes. Além de intensa exploração turística, outra questão observada e que não lhe é dada a devida importância é a ocupação e exploração da área que margeia o lago, sem que haja um planejamento dessa ocupação. 
Para uma melhor compreensão da situação que motivou este estudo, torna-se necessária uma breve explanação sobre a criação da barragem que formou o lago Serra da Mesa, onde fora implantada a Usina.

Conforme dados da MULTIGEO, no relatório do Programa de Monitoramento Limnológico $^{1}$ e da Qualidade da Água do Reservatório da UHE Serra da Mesa fornecido pelo Instituto Brasileiro do Meio Ambiente e dos Recursos Naturais Renováveis (IBAMA), a UHE Serra da Mesa localizada na Bacia do Alto Tocantins, em Goiás, foi criada para atender o mercado de energia elétrica. Entrou em operação em 1998 com três unidades geradoras (1.275MW). Possui o maior reservatório do Brasil em volume de água, com 54,4 bilhões de $\mathrm{m}^{3}$ de água numa área de $1.780 \mathrm{Km}^{2}$ de espelho d’água.

O empreendimento afetou os municípios de Barro Alto, Campinaçu, Campinorte, Colinas do Sul, Minaçu, Niquelândia, Santa Rita do Novo Destino e Uruaçu. Atualmente a usina está retomando o enchimento do reservatório até sua cota máxima de 460 m, nível em que a água do reservatório deveria alcançar, acima do nível médio do mar, e que jamais foi conseguida. O Lago foi projetado como o maior reservatório artificial de água doce do Brasil e terceiro da América Latina. Sua extensão dificulta a fiscalização de forma abrangente, o que o torna suscetível aos efeitos nocivos da ação humana.

O empreendimento certamente traz benefícios para a população local em atendimento a demanda por energia elétrica. Porém, estudos vêm sendo realizados por especialistas da área avaliando os impactos ambientais que empreendimentos hidrelétricos podem causar. Tais estudos trazem ao nosso conhecimento que empreendimentos dessa natureza possuem impactos significativos. Tem-se como exemplo, a massa biológica que fica submersa com o enchimento dos reservatórios que promove a ausência de oxigênio e aumento da temperatura da água, o que conseqüentemente, aumenta a população de algas que são muito prejudiciais à qualidade da água, aos peixes e a saúde humana de um modo geral.

O Instituto Serrano Neves (ISN), uma organização não-governamental voltada aos estudos jurídicos e ambientalistas, com ênfase em recursos hídricos, mais especificamente aos do Lago da Serra da Mesa, em Goiás, vem realizando o trabalho de divulgação dos problemas ambientais em Uruaçu, levando ao conhecimento da comunidade do município a necessidade de cobrar dos órgãos competentes ações de proteção ao meio ambiente.

\footnotetext{
${ }^{1}$ Estudo das águas interiores, independentemente de suas origens (estudadas pela hidrografia), mas verificando as dimensões e concentração de sais, em relação aos fluxos de matéria e energia e as suas comunidades bióticas.
} 
Neste trabalho pretende-se saber se o IBAMA está atuando adequadamente, ou seja, se medidas preventivas ou reparativas estão sendo aplicadas no sentido de prevenir ou reparar possíveis danos causados. Na busca por respostas a essa questão, tornou-se necessário também o entendimento do conceito da Responsabilidade Social e Corporativa no âmbito da administração pública. Que será discutida à luz de suas aplicações e benefícios que ela traz à nova gestão pública para atender adequadamente a sociedade.

\subsection{Formulação do problema}

Temos o conhecimento que a atividade de fiscalização do IBAMA visa diminuir a ação predatória do homem sobre a natureza, mas, como verificar quais atividades estão sendo executadas e sua efetividade?

Diante da degradação ambiental ocorrida desde a construção da Usina Hidrelétrica de Serra da Mesa e que perdura ainda hoje, em conseqüência principalmente da ação humana, constata-se a necessidade de verificar o desempenho dos órgãos ambientais competentes na fiscalização do problema. Nesse caso, o estudo analisou exclusivamente a organização IBAMA por que suas atribuições estão diretamente ligadas aos problemas ambientais que motivaram essa pesquisa.

Portanto, neste trabalho pretende-se responder a seguinte pergunta: o IBAMA como órgão de fiscalização ambiental, tem atuado efetivamente em relação à poluição do Lago de Serra da Mesa, especificamente no município de Uruaçu em Goiás?

A cidade de Uruaçu encontra-se localizada às margens da BR-153, KM 200, norte de Goiás, 280 quilômetros de Goiânia (capital do Estado) e 249 quilômetros de Brasília, Distrito Federal. A cidade conta com uma área territorial de 2.149,7 quilômetros quadrados e uma população estimada em 36.949 habitantes, segundo números do Instituto Brasileiro de Geografia e Estatística (IBGE) ${ }^{2}$.

O município de Uruaçu-GO é o único banhado pelas águas do lago da UHE Serra da Mesa, o que gera preocupação com a saúde e qualidade de vida da população local, em razão da poluição e contaminação observada na água deste reservatório.

\footnotetext{
${ }^{2}$ Fonte: IBGE, Disponível em: http://www.ibge.gov.br/cidadesat/topwindow.htm?1 Acesso em: Març. 2011
} 


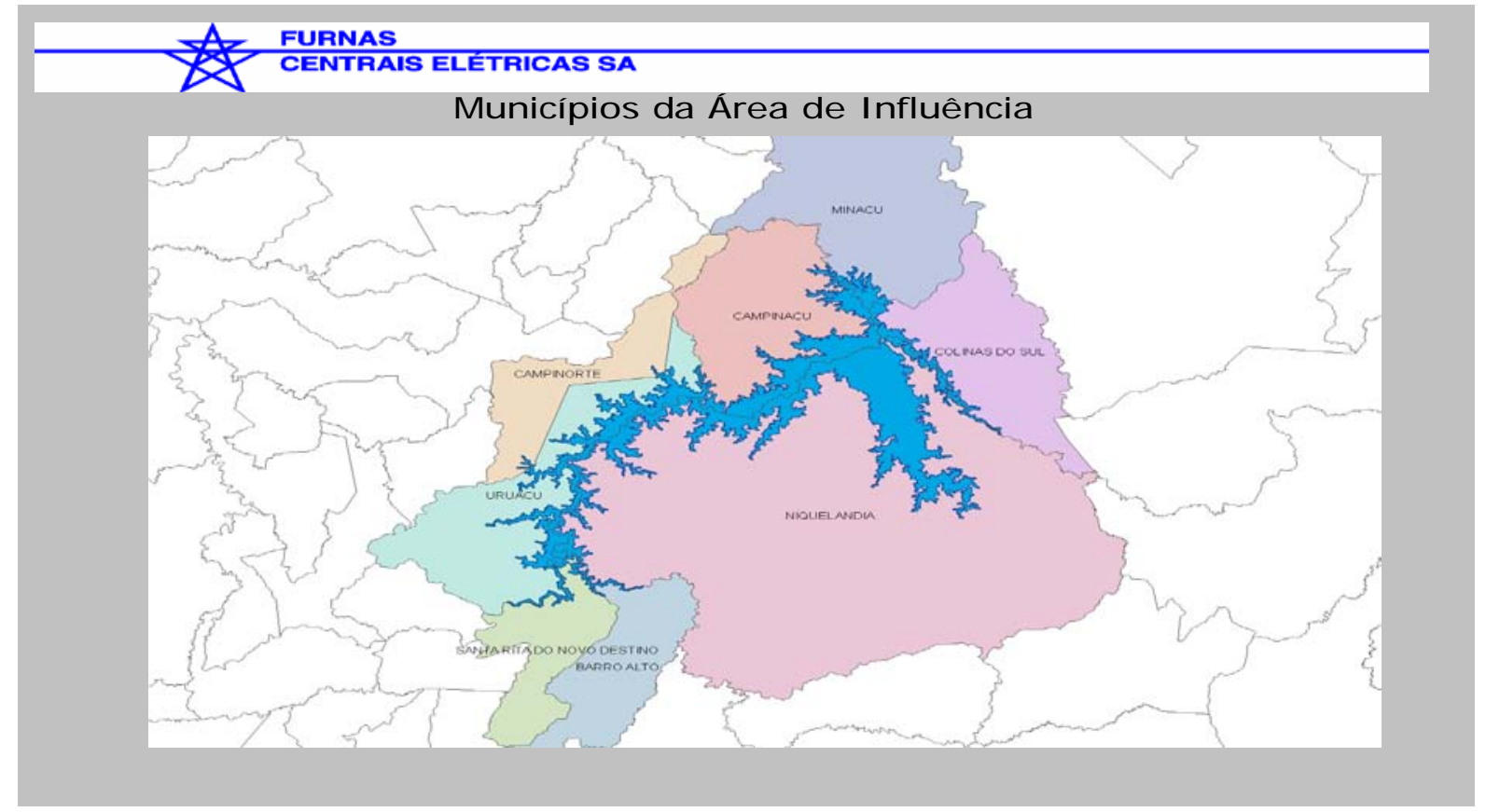

Fonte: IBAMA

\subsection{Objetivo Geral}

Analisar a atuação do IBAMA frente à poluição do Lago da UHE Serra da Mesa, na região de Uruaçu - GO.

\subsection{Objetivos Específicos}

Constatar a poluição das águas do Lago Serra da Mesa, suas causas e conseqüências;

Identificar os instrumentos de políticas ambientais existentes e suas aplicações;

Verificar os procedimentos de fiscalização adotados pelo IBAMA em relação à poluição observada no lago. 


\subsection{Justificativa}

O interesse pelo tema foi despertado em razão da experiência própria, diante da convivência com o problema da degradação ambiental existente na região. Ao observar a poluição do Lago, cheio de garrafas pets, de lixo, de redes abandonadas por pescadores, de embalagens de agrotóxicos, do esgoto trazido pelos rios, etc., desperta a vontade de saber o que os órgãos competentes de fiscalização estão fazendo para amenizar o problema.

Outro ponto muito importante está relacionado à saúde humana, pois a população da região e os turistas utilizam a água do lago para lazer e consomem peixes do lago, além disso, existem lavouras que são irrigadas com essas águas. Portanto, existem grandes riscos para a saúde dessas pessoas.

Destaca-se ainda a questão das ocupações irregulares, que vêm aumentando significativamente na orla do lago, com a criação de condomínios, e invasões. Nesses locais não há tratamento do esgoto nem serviços de coleta de lixo, fatores considerados como principais causas da poluição observada no lago.

Este trabalho pretende dar a sua contribuição no sentido de alertar a sociedade sobre os danos ambientais ocorridos e suas conseqüências, além de verificar a atuação do principal órgão competente fiscalizador, o IBAMA, procurando identificar possíveis falhas em seu processo de gestão administrativa. 


\section{REFERENCIAL TEÓRICO}

Será apresentada aqui uma breve discussão teórica a cerca do tema Gestão Ambiental, Responsabilidade Social e Corporativa, que serviu de base para a elaboração da pesquisa, bem como para a análise e interpretação dos dados coletados.

\subsection{A Questão Ambiental e Responsabilidade Social Corporativa}

Atualmente, presencia-se no Brasil e no mundo uma nova tendência, o desenvolvimento da consciência social frente aos efeitos negativos do crescimento econômico e suas conseqüências, ou seja, os impactos ambientais oriundos desse crescimento.

Sobre o conceito de Impacto Ambiental, Nascimento (2008) explica:

\footnotetext{
Segundo resolução do Conselho Nacional de Meio Ambiente (CONAMA), ${ }^{\circ}$ 001/86, art. $1^{\circ}$, trata-se de qualquer alteração das propriedades físicas, químicas e biológicas do ambiente natural, causada por qualquer forma de matéria ou energia resultante das atividades humanas que, direta ou indiretamente, afetam a saúde, a segurança e o bem-estar da população; as atividades sociais e econômicas; as biotas; as condições estéticas e sanitárias, do ambiente natural; e a qualidade dos recursos ambientais. (NASCIMENTO, 2008, p. 18).
}

Segundo o autor, esses aspectos são abordados na discussão da construção do conceito de desenvolvimento sustentável e o embate com o crescimento econômico, “aquele cujas necessidades do presente são atendidas sem comprometer a possibilidade das gerações futuras”. Dessa forma, um pensamento se sobressai, sendo necessário acreditar que é possível um equilíbrio entre esses dois vetores, crescimento econômico e desenvolvimento sustentável. A idéia principal percebida como amenizadora e quem sabe até solucionadora a longo prazo, é uma questão de educação, de uma cultura que precisa ser mudada sobre consumismo. Um indivíduo não precisa, por exemplo, trocar seu aparelho celular a cada novo modelo lançado. Está evidente que o crescimento industrial trouxe ao longo dos anos, impactos negativos à sociedade.

Sob a ótica do mesmo autor este conceito é composto por três importantes dimensões que estão inter-relacionadas: o meio ambiente, a economia e as questões relativas ao bem-estar 
social. Dessa forma, torna-se necessário entender às variáveis dessa relação, no presente e no futuro, e como se dá a aplicação desse conceito à realidade.

Entende-se que nesse momento entra o papel da Responsabilidade Social Corporativa, estabelecendo uma coerência entre ação e discurso. Para um melhor entendimento destaco uma idéia de RSC elaborada por um importante empresário do setor industrial brasileiro, chamado Emerson Kapaz, mencionado por Souza (2008):

\footnotetext{
Responsabilidade Social nas empresas significa uma visão empreendedora mais preocupada com o entorno social em que a empresa está inserida, ou seja, sem deixar de se preocupar com a necessidade de geração de lucro, colocando-o não como um fim em si mesmo, mas sim como um meio para se atingir um desenvolvimento sustentável e com mais qualidade de vida (SOUZA 2008, p. 146)
}

Em se tratando da Responsabilidade Social Corporativa no âmbito das empresas públicas, Adorno Júnior (2010) em seu artigo, discute as contribuições que a responsabilidade social pode trazer. $\mathrm{O}$ autor destaca a necessidade de transparência com que os serviços públicos devem agir em relação aos cidadãos, não somente em matéria de acesso à informação, mas também nos resultados obtidos por instituições públicas no cumprimento da sua missão.

Dessa forma, entende-se que os cidadãos deveriam encontrar nas instituições da Administração Pública, as respostas adequadas aos seus problemas, como neste caso da poluição das águas do Lago de Serra da Mesa.

\subsection{Instrumentos de Políticas Ambientais Existentes e Suas Aplicações}

Em relação a bem-estar social, Ferreira (2007) aborda a compreensão de que indivíduos se reúnem para viver em sociedade, formando um grupo social, esse grupo social carece de necessidades que devem ser atendidas e para tal formam-se as organizações. Assim, surge o Estado, constituído por um povo, território e governo. O povo, para ter suas necessidades atendidas, delega competência ao governo a fim de prover suas necessidades, e para que isso aconteça contribui com impostos para que haja uma contrapartida do governo às suas demandas.

Ferreira, (2007, p. 12) afirma que “Administração Pública é o conjunto de órgãos criados pelo governo [...] para atender às necessidades do povo. Cada órgão tem uma função 
especializada, e o conjunto de órgãos ou pessoas jurídicas forma o serviço público”. O IBAMA faz parte desse serviço público e tem função especializada, segundo o próprio órgão, vem procurando cumprir seus objetivos institucionais relativos ao licenciamento ambiental, à autorização de uso dos recursos naturais, à fiscalização, monitoramento e controle ambiental. Mas a situação de degradação observada no Lago Serra da Mesa nos leva a acreditar que a fiscalização do IBAMA na região de interesse não acontece de forma eficiente, para amenizar os problemas ambientais da região.

De acordo com Nascimento (2008, p. 57) a Gestão Ambiental Pública "é entendida como a gestão realizada por órgãos públicos no sentido da proteção e preservação do meio ambiente”. E “As atribuições variam conforme os níveis federal, estadual e municipal”.

O autor define a estrutura de gestão ambiental pública no Brasil da seguinte forma:

a) Órgão superior: Conselho de Governo;

b) Órgão consultivo e deliberativo: Conselho Nacional de Meio Ambiente (CONAMA);

c) Órgão Central: Ministério do Meio Ambiente (MMA);

d) Órgão Executor: Instituto Brasileiro do Meio Ambiente (IBAMA);

e) Órgãos setoriais;

f) Órgãos seccionais; e

g) Órgãos locais.

As normas são elaboradas pelo Ministério do Meio Ambiente (MMA). Na esfera federal, a fiscalização das normas é de responsabilidade do Instituto Brasileiro do Meio Ambiente (IBAMA), órgão que executa as leis ambientais ou mesmo as resoluções do Conselho Nacional de Meio Ambiente (CONAMA).

De acordo com Nascimento (2008, p. 58), os órgãos públicos detêm o poder de comando e controle, que são instrumentos de regulamentação, ou seja, que estabelece padrões e controlam se esses padrões estão sendo respeitados. Por exemplo, os órgãos de controle ambiental têm a função de estabelecer o padrão de quantos PPM (partes por milhão) de substâncias podem ser lançadas em um rio por uma empresa. Além do poder de estabelecer padrões também o de estabelecer penalidades.

Ainda segundo Nascimento (2008), observa-se que as licenças ambientais necessárias no caso de grandes obras a serem implementadas, como a UHE de Serra da Mesa, também são outro instrumento de comando e controle. No processo do licenciamento ambiental é verificada a viabilidade ou não de localização e implementação do empreendimento. Uma vez 
considerado viável, inicia-se o processo de licenciamento ambiental, com a emissão de três licenças: Licença Prévia (LP), Licença Instalação (LI) e Licença de Operação (LO).

Na licença prévia são realizados os Estudos de Impacto Ambiental (EIA) e o Relatório de Controle Ambiental (RIMA). Fase em que é vistoriado o local do empreendimento e todos os interessados poderão se manifestar pró ou contra o empreendimento através de uma audiência pública.

Caso tenha ocorrido a liberação da LP, a próxima etapa é a licença de instalação, que autoriza o início da construção do empreendimento para que esta seja concedida ao interessado, que deve manter o projeto final compatível com as condições de seu deferimento.

A Licença de Operação autoriza o funcionamento do empreendimento, nela estão determinados os métodos de controle e as condições de operação, será concedida depois de verificada a eficácia das medidas de controle ambiental estabelecidas.

Outro instrumento importante é o Instrumento de Planejamento, que de acordo com Nascimento (2008), tem como objetivo propiciar a melhor qualidade de vida possível, com a preservação, a melhoria e a recuperação da qualidade ambiental.

Para Varela (2008) “A discussão sobre o uso de ferramentas de gestão pública passa pelo conceito de externalidades [...]”. "Externalidades são consideradas falhas no sistema de mercado; ocorrem quando as atividades de produção e/ou consumo geram custos (ou benefícios) que não são adequadamente contabilizados pelo mercado”. (VARELA, 2008, pg. 251)

Como bem define Varela (2008):

\begin{abstract}
Quando há externalidades ligadas a bens de propriedade comum e a um grande número de indivíduos e/ou empresa fica difícil conseguir um acordo entre as partes. Nestes casos, o governo deve atuar, punindo os causadores das externalidades e agindo em favor dos interesses das vítimas. Existe um grande número de instrumentos de políticas ambientais possíveis de serem utilizados para solucionar os problemas relativos ao meio ambiente, mas, os governos utilizam um número bastante limitado. Qualquer que seja a solução escolhida, a finalidade é sempre tentar internalizar os custos dos problemas ambientais (externalidades).

Os bens de propriedade comum são considerados não-excludentes, isto é, estão disponíveis para todos os indivíduos, inclusive para os que não pagam por eles, e é parcialmente rivais, o que significa que o uso desses bens por um indivíduo afeta a sua disponibilidade para os outros indivíduos. Em função de suas características esses bens tendem a ser utilizados em excesso. (VARELA 2008, p.252)
\end{abstract}

Fica o entendimento de que os recursos ambientais, como o ar, a água, etc., são considerados bens de propriedade comum e seus direitos de propriedade não são bem definidos pela legislação. 
Para Serôa da Motta \& Reis (1992) apud Varela (2008, p. 253) “os instrumentos de comando e controle são caracterizados pela utilização de formas de regulação direta e indireta, via legislação e normas”.

Ainda segundo os autores, no Brasil, a gestão ambiental tem se pautado pelo uso de regulação, ou seja, instrumentos de comando e controle, classificados em quatro categorias: a) padrões ambientais de qualidade e de emissão; b) controle do uso do solo; c) licenciamento (estudo de impacto ambiental - EIA/relatório de impacto ambiental RIMA); e, d) penalidades (multas, compensações, etc).

Da abordagem sobre os instrumentos de políticas ambientais existentes observa-se que sua aplicabilidade é de grande relevância como medidas preventivas dos danos ambientais causados por empreendimentos potencialmente causadores de qualquer tipo de degradação.

\subsection{Principais Causas e Conseqüências da Poluição do Lago de Serra da Mesa}

A necessidade do estudo foi despertada diante os indícios da poluição e contaminação no Lago de Serra da Mesa, desde os observados no local de interesse mediante contato direto como a poluição visível do lixo que se acumula nas margens do lago, bem como os indícios mencionados por diversos canais de comunicação.

O conhecimento dos fatos se deu também por meio de matérias publicadas em jornais e internet, por entidades locais preocupadas com a situação da degradação ambiental ocorrida na região.

O Instituto Serrano Neves é um exemplo de organização não governamental que tem realizado um bom trabalho no sentido de divulgar e alertar a todos, comunidade e órgãos competentes, em relação a essa questão.

Dentre os vários problemas divulgados o ISN destacou a contaminação da água por algas que podem conter toxicidade; a contaminação pela presença de mercúrio, alumínio, ferro, fosfato; a eutrofização que é decorrente da inundação de grandes massas de vegetação (fitomassa) e o conseqüente aumento da disponibilidade de nutrientes (fósforo e nitrogênio). A estratificação se deve à criação de ambientes com reduzida capacidade de renovação da água, 
assim como pelo aquecimento da água, como ocorre na implantação de reservatórios, como o Lago Serra da Mesa.

Agravando ainda mais a situação, o Rio das Almas transporta ao lago o esgoto urbano dos municípios que margeiam o rio; somado-se ao lixo do entorno do Distrito Federal que é levado pelo Rio maranhão; ao lixo produzido pela população das ocupações irregulares às margens do lago; à presença de vetores de doenças endêmicas como febre amarela, esquistossomose, raiva, leishmaniose, malária e dengue.

Diante dos impactos mencionados, na seqüencia deste estudo junto ao IBAMA, procurou-se constatar a real situação da contaminação da água no reservatório da UHE Serra da mesa.

Os resultados aqui apresentados foram pesquisados no Programa de Monitoramento Limnológico e da Qualidade da Água do Reservatório da UHE Serra da Mesa, relatório final, 2005 a 2007, elaborado pela MULTIGEO Mineração, Geologia e Meio Ambiente Ltda. Ressaltando que no relatório foram aplicados os parâmetros estabelecidos pela Resolução CONAMA 357/2005 ${ }^{3}$.

Segundo a Resolução CONAMA 357/2005, as águas do reservatório de Serra da Mesa se enquadram na classe 2, [...] "podendo, portanto, ser destinadas ao abastecimento público após tratamento convencional, à proteção das comunidades aquáticas, à recreação de contato primário, à irrigação de hortaliças e plantas frutíferas e à aqüicultura e atividades de pesca”.

Destaca-se que o relatório se refere ao estudo no período de 2005 a 2007, sendo, portanto, o estudo mais recente já concluído da qualidade da água do reservatório. Novos estudos foram determinados pelo IBAMA, mas ainda estão em fase de análise.

A pesquisa realizada em campo propiciou o acesso ao referido relatório, do qual se pôde tirar cópia xerográfica, o que facilitou a constatação dos dados referentes à qualidade da água.

Segundo o relatório, a quase totalidade dos parâmetros apresentou resultados compatíveis com os limites estabelecidos. Porém, alguns parâmetros se apresentaram em desacordo com a legislação.

Foram constatadas alterações dos seguintes elementos: oxigênio dissolvido (OD), baixa concentração de oxigênio em diversas profundidades do reservatório; a turbidez da água foi superior ao limite máximo estabelecido, segundo o estudo estiveram relacionadas com as chuvas que ocorreram durante o período da coleta; o fósforo total foi detectado com valores

\footnotetext{
${ }^{3}$ Dispõe sobre a classificação dos corpos de água e diretrizes ambientais para seu enquadramento, bem como estabelece as condições e padrões de lançamentos de afluentes, e dá outras providências.
} 
acima do limite em alguns pontos; o ferro dissolvido foi detectado com valores acima do limite estabelecido pela legislação em vários pontos de coleta.

Neste relatório foi esclarecido que o mercúrio:

[...] é um metal que possui características de toxidade aos organismos aquáticos, e que também pode refletir na saúde humana. [...] são numerosos os incidentes epidemiológicos relacionados a esse elemento através da contaminação da água e de pescados. Os níveis de mercúrio nos pontos considerados no estudo variaram [...], o valor máximo encontrado em Serra da Mesa situa-se muito abaixo do limite estabelecido. (MULTIGEO, 2007, p. 114).

Com relação às Cianobactérias mencionadas nas divulgações do ISN, o estudo revela que:

Embora as cianobactérias tenham ocorrido em baixas densidades no reservatório, elas são algas com potencial tóxico, que em condições favoráveis, como elevada entrada de matéria orgânica no sistema associada às temperaturas acima de $20^{\circ} \mathrm{C}$ entre outros fatores, têm crescimento rápido levando às florações e conseqüentemente ocasionar a deterioração da qualidade da água do reservatório em curto prazo. (MULTIGEO, p. 162).

Para concluir o relatório destaca a importância do monitoramento limnológico e da qualidade das águas do reservatório no sentido deste ser uma importante ferramenta para o registro de alterações ao longo do tempo, indicando com antecedência a necessidade de medidas de controle, evitando riscos aos usos dos corpos d’água. 


\section{MÉTODOS E TÉCNICAS DE PESQUISA}

\subsection{Tipo e descrição geral da Pesquisa}

Este estudo utilizou o método qualitativo de pesquisa. Trata-se de uma pesquisa descritiva, os fenômenos foram descritos por meio dos significados manifestados pelo ambiente, ou seja, a realidade foi conhecida segundo a perspectiva dos sujeitos participantes da pesquisa.

Assim, os resultados foram expressos, principalmente, na forma de transcrição de entrevistas, uma vez que a técnica utilizada para coletar os dados foi a entrevista semiestruturada. A pesquisa buscou o conhecimento, a descrição e identificação de possíveis falhas no processo de gestão pública, ou seja, da atuação do principal órgão fiscalizador dos problemas ambientais da região, o Instituto Brasileiro do Meio Ambiente e dos Recursos Naturais Renováveis - IBAMA.

\subsection{Caracterização da Organização, Setor ou Área do Objeto de Estudo}

O Instituto Brasileiro do Meio Ambiente e dos Recursos Naturais Renováveis (IBAMA) é uma autarquia federal dotada de personalidade jurídica de direito público, autonomia administrativa e financeira, vinculada ao Ministério do Meio Ambiente, conforme art. 20 da Lei $n^{\circ}$ 7.735, de 22 de fevereiro de 1989. É o órgão federal executor da Política Nacional do Meio Ambiente com atuação em todas as unidades da federação (Estados, Municípios e Distrito Federal).

Nasceu da fusão de órgãos públicos cujas funções eram relacionadas à gestão do uso dos recursos naturais e meio ambiente, dos quais o Instituto Brasileiro de Desenvolvimento Florestal (IBDF), Superintendência de Desenvolvimento da Pesca (SUDEPE), Superintendência de Desenvolvimento da Borracha (SUDHEVEA) e Secretaria de Meio Ambiente (SEMA). Isto mostra que o IBAMA foi concebido com a responsabilidade de executar a política ambiental do país. (Fonte: www.ibama.gov.br) 
Segundo Plano Diretor de Tecnologia da Informação (PDTI) do IBAMA, a instituição conta com centenas de unidades descentralizadas operacionais. Dessas unidades: 27 são Superintendências Estaduais; 127 são Escritórios Regionais; 10 são Gerências Executivas; 17 Centros de Triagem de Animais Silvestres; 4 Centros Especializados, 1 Posto Avançado de Fiscalização e 1 Base de Operações.

Tem como missão executar as políticas nacionais de meio ambiente, referentes às atribuições que lhe são conferidas, visando à conservação, recuperação e uso sustentável dos recursos ambientais para as presentes e futuras gerações. (Fonte: www.ibama.gov.br)

No que diz respeito às atribuições do IBAMA, cabe aqui esclarecer que a Lei $\mathrm{n}^{\circ}$ 11.561/2007, que criou o Instituto Chico Mendes de Conservação da Biodiversidade (ICMBio), também altera o art. $2^{\circ}$ da Lei ${ }^{\circ}$ 7.735/89, (lei de criação do IBAMA). De acordo com o Plano Diretor de Tecnologia da Informação (PDTI) do IBAMA $^{4}$ as atribuições do órgão são confirmadas da seguinte forma:

I - exercer o poder de polícia ambiental de âmbito federal;

II - executar ações das políticas nacionais de meio ambiente, referentes às atribuições federais, relativas ao licenciamento ambiental, ao controle da qualidade ambiental, à autorização de uso dos recursos naturais e à fiscalização, monitoramento e controle ambiental, observadas as diretrizes emanadas do Ministério do Meio Ambiente; e

III - executar as ações supletivas da União, de conformidade com a legislação ambiental vigente.

$\mathrm{O}$ art. $2^{\circ}$ do Anexo I apresenta as seguintes ações que o IBAMA deve desenvolver no cumprimento de suas competências:

I - proposição e edição de normas e padrões de qualidade ambiental;

II - zoneamento ambiental;

III - avaliação de impactos ambientais;

IV - licenciamento ambiental de atividades, empreendimentos, produtos e processos considerados efetiva ou potencialmente poluidores, bem como daqueles capazes de causar degradação ambiental, nos termos da legislação em vigor;

V - implementação dos Cadastros Técnicos Federais de Atividades e Instrumentos de Defesa Ambiental e de Atividades Potencialmente Poluidoras ou Utilizadoras dos Recursos Ambientais;

VI - fiscalização e aplicação de penalidades administrativas ambientais ou compensatórias pelo não-cumprimento das medidas necessárias à preservação ou correção da degradação ambiental, nos termos da legislação em vigor;

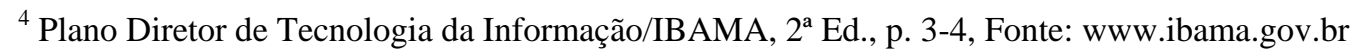


VII - geração, integração e disseminação sistemática de informações e conhecimentos relativos ao meio ambiente;

VIII - disciplinamento, cadastramento, licenciamento, monitoramento e fiscalização dos usos e acessos aos recursos ambientais, florísticos e faunísticos;

IX - análise, registro e controle de substâncias químicas, agrotóxicos e de seus componentes e afins, conforme legislação em vigor;

$\mathrm{X}$ - assistência e apoio operacional às instituições públicas e à sociedade, em questões de acidentes e emergências ambientais e de relevante interesse ambiental;

XI - execução de programas de educação ambiental;

XII - fiscalização e controle da coleta e transporte de material biológico;

XIII - recuperação de áreas degradadas;

XIV - auxiliar na implementação do Sistema Nacional de Informações sobre o Meio Ambiente - SINIMA;

XV - aplicação, no âmbito de sua competência, dos dispositivos e acordos internacionais relativos à gestão ambiental;

XVI - monitoramento, prevenção e controle de desmatamentos, queimadas e incêndios florestais;

XVII - elaboração do sistema de informação para a gestão do uso dos recursos faunísticos, pesqueiros e florestais;

XVIII - elaboração e estabelecimento de critérios, padrões e proposição de normas ambientais para a gestão do uso dos recursos pesqueiros, faunísticos e florestais; e

XIX - elaboração do Relatório de Qualidade do Meio Ambiente.

Por ser o principal órgão de controle e fiscalização dos recursos naturais, pretendeu-se verificar sua atuação, uma vez que o objeto desse estudo foi saber que medidas estão sendo tomadas pelo órgão em relação à poluição do Lago de Serra da Mesa na região de Uruaçu/GO.

\subsection{Participantes do Estudo}

Para coletar as informações necessárias sobre o Licenciamento da UHE Serra da Mesa, a constatação da poluição e contaminação da água do reservatório e demais informações que possibilitem uma análise da atuação do IBAMA, proposta neste estudo, tentou-se um primeiro contato com o IBAMA de Brasília, onde foi informado que não havia dados sobre a região de Goiás. Portanto, as informações necessárias ao estudo foram obtidas primeiramente no Escritório Regional do IBAMA em Uruaçu - GO, também no IBAMA de Goiânia, que é o atual responsável pela renovação do licenciamento da UHE Serra da Mesa.

Participaram do presente estudo o Responsável pelo Escritório Regional do IBAMA de Uruaçu - GO, que após contato presencial e telefônico respondeu aos questionamentos da 
entrevista via e-mail; uma Analista Ambiental do Núcleo de Licenciamento Ambiental do IBAMA de Goiânia - GO; e, uma Técnica de Fiscalização do Departamento de Fiscalização do mesmo órgão, participaram individualmente, de uma entrevista semi estruturada que fora aplicada de forma presencial.

\subsection{Caracterização dos Instrumentos de Pesquisa}

A técnica utilizada como instrumento para a coleta dos dados foi a entrevista semi estruturada, onde as questões foram respondidas seguindo um roteiro elaborado pelo entrevistador, mas sem seguir rigidamente a uma seqüência das perguntas. Na coleta dos dados foi empregada também a análise documental, também chamada pesquisa documental, pois envolveu a investigação em documentos internos á organização.

Para elaboração da entrevista levou-se em conta a necessidade de levantar dados referentes a poluição da água do Lago Serra da Mesa, dados que comprovassem a poluição, causa principal pelo interesse da pesquisa; levantamento de dados que possibilitassem a identificação e descrição da atuação do IBAMA em relação à poluição da água, caso a poluição observada fosse comprovada. O estudo foi delimitado a região de Uruaçu em Goiás, em razão da poluição ter sido observada pelo pesquisador nessa região.

A pesquisa se deu em três etapas uma vez que os dados coletados no município de Uruaçu não foram suficientes para a proposta deste estudo. Inicialmente, na cidade de Uruaçu, foi realizada uma entrevista no Escritório Regional do IBAMA. Para uma melhor organização dos dados obtidos esta primeira etapa foi denominada Pesquisa de Campo 1.

Na segunda etapa foi realizada entrevista com uma Analista Ambiental do Núcleo de Licenciamento Ambiental do IBAMA de Goiânia - GO, onde foram abordadas questões relativas ao licenciamento da UHE Serra da Mesa, denominada Pesquisa de Campo 2. Na terceira etapa foi realizada entrevista com uma Técnica em Fiscalização do Departamento de Fiscalização do mesmo órgão, em Goiânia-GO, denominada Pesquisa de Campo 3. 


\subsection{Procedimentos de Coleta e de Análise de Dados}

Para aplicação da entrevista houve uma prévia explicação quanto aos objetivos da pesquisa, seguida da apresentação do Termo de Consentimento Informado solicitando a participação na entrevista como colaborador, e apresentação de um roteiro contendo os questionamentos de interesse. A aplicação da entrevista se deu de forma presencial e foi gravada com autorização prévia dos entrevistados.

Os entrevistados responderam os quesitos de forma espontânea. O entrevistador recebeu autorização para consultar documentos internos que serviram para comprovar a poluição da água, e entender o processo de licenciamento da UHE Serra da Mesa desde o início de sua instalação. Onde se pode comprovar a responsabilidade do IBAMA nesse processo somente à partir de 2005, quando lhe foi delegada esta função.

Durante a entrevista o entrevistado forneceu relatórios para que fossem tiradas cópias xerográficas sobre estudos realizados pelo empreendedor da UHE Serra da Mesa, para avaliação da qualidade da água do reservatório; cópias de dados referentes ao licenciamento do empreendimento, informatizados; além das informações referentes à atuação do órgão, como fiscalizador. A transcrição dos dados coletados na entrevista foi realizada posteriormente por meio da gravação obtida durante a entrevista, e, da análise dos documentos fornecidos, os quais constam em anexo ao presente estudo.

Os Analistas Ambientais que analisaram a documentação que contém os levantamentos e planos encaminhados ao IBAMA, chegaram a conclusão e emitiram algumas recomendações que estão detalhadas no Parecer Técnico em anexo ao presente estudo. (ANEXO C).

Das providências de reparação e de mitigação dos danos ambientais decorrentes da instalação da usina e estabelecidas pelo IBAMA em julho de 2010, não se tem conhecimento ainda da sua aplicabilidade, se esses planos já estão concluídos ou se estão em andamento.

Em relação a competência dos estudos de impacto ambiental após a instalação da UHE Serra da Mesa os dados demonstraram que é competência do empreendedor. O IBAMA apenas estabelece objetivamente às providências de reparação e de mitigação dos danos ambientais quando ocorridos. No caso o IBAMA estabelece medidas a serem implementadas e analisa se as medidas estão seguindo os parâmetros e prazos determinados. 
Em relação a existência de estudos sobre a poluição do Lago Serra da Mesa, os dados constataram que esses estudos são realizados por empresas contratadas pelos empreendedores. No caso, FURNAS Centrais Elétricas S.A. e SEMESA S.A. ${ }^{5}$ que contratou a MULTIGEO Mineração, Geologia e Meio Ambiente Ltda., para dar continuidade ao programa desenvolvido desde 1996, com a supervisão de técnicos do Departamento de Meio Ambiente de FURNAS. Ficando sob a responsabilidade do IBAMA a solicitação e análise desses estudos.

De acordo com dados coletados, recentemente o IBAMA pediu um estudo sobre os níveis de mercúrio na água, um levantamento do nível de mercúrio no pescado, e será feito um monitoramento do mercúrio na água e nos sedimentos

Por meio das informações coletadas referente a atuação do órgão, obteve-se as respostas necessárias para saber se o IBAMA como órgão fiscalizador ambiental, tem atuado efetivamente no combate a poluição do lago de serra da mesa na região de Uruaçu - GO.

\footnotetext{
${ }^{5}$ Serra da Mesa Energia S.A.
} 


\section{RESULTADOS E DISCUSSÃO}

Para se chegar a uma análise dos dados coletados de uma forma mais precisa possível, tentou-se identificar os tópicos de maior relevância. Em uma primeira análise nesse estudo foi escolhida a área que mereceu maior exploração, a fiscalização. Nota-se que esta área oferece dados para uma representação aproximada da realidade estudada, uma vez que a fiscalização atinge diretamente as ações humanas que causam a degradação ambiental.

Para testar a validade das informações aqui prestadas buscou-se a credibilidade dos dados por parte dos informantes, confrontando-os com a revisão dos documentos fornecidos. Dentre esses documentos constam: Boletim técnico do Programa de Monitoramento Limnológico e da Qualidade da Água do Reservatório da UHE - Serra da Mesa; Nota Técnica $n^{\circ}$ 10/2010 - COLIC/DGPA/IBAMA-GO; Parecer Técnico n n 20/2010 COLIC/DGPA/IBAMA-GO; e, relatórios de autos de infração lavrados por município, referente aos exercícios 2009 e 2010. (ANEXOS D e E).

Foram abordadas questões relativas à atuação do órgão, tais como: dados comprovantes da poluição da água do reservatório da UHE Serra da Mesa, dados referente ao Licenciamento da Usina, dos mecanismos institucionais de controle e supervisão dos impactos ambientais ocorridos no Lago Serra da Mesa; das medidas efetuadas visando diminuir a ação predatória do homem sobre a natureza; a existência de políticas de fiscalização e educativa sendo aplicadas atualmente; e, quais os principais trabalhos ou procedimentos de fiscalização executados pelo órgão, entre outras informações.

Os dados de cada etapa da pesquisa serão apresentados nos Quadros 1; 2; e, 3. Tabulação e Apresentação dos Dados, e, os pontos considerados relevantes para uma análise da atuação do IBAMA serão destacados com asteriscos (*).

Na primeira etapa da pesquisa de campo, que teve como participante do estudo o Chefe do Escritório Regional do IBAMA/URUAÇU/GO, obteve-se os dados demonstrados no quadro 1. Os dados se referem a atuação do IBAMA no município de Uruaçu/GO.

Foram considerados pontos positivos para ações consideradas efetivas, pontos negativos para a falta de ações efetivas, e pontos neutros quando considerados sem muita relevância para a análise. 


\begin{tabular}{|c|c|c|c|c|}
\hline & PESQUISA DE CAMPO - $1^{\mathrm{a}}$ ETAPA & $\mathbf{P +}$ & $\mathbf{P}-$ & PN \\
\hline 01 & $\begin{array}{l}\text { Sobre a poluição da água do reservatório da UHE Serra da Mesa: } \\
\text { O IBAMA de Uruaçu afirma não ter conhecimento de relatório } \\
\text { sobre vistoria ou autuação de poluição no lago*. Não há dados } \\
\text { que comprovem a poluição*. Encaminha a questão para o } \\
\text { IBAMA de Goiânia/GO. }\end{array}$ & & $\mathbf{P}-$ & \\
\hline 02 & $\begin{array}{l}\text { Sobre o Licenciamento da UHE Serra da Mesa: O IBAMA de } \\
\text { Uruaçu não tem dados suficientes para afirmar com certeza se o } \\
\text { empreendimento obteve as licenças*necessárias, ou renovação } \\
\text { das mesmas. Encaminha a questão para o NLA de Goiânia/GO. }\end{array}$ & & $\mathbf{P}-$ & \\
\hline \multicolumn{5}{|c|}{$\begin{array}{l}\text { OBS: A falta de conhecimento das questões } 1 \text { e } 2 \text { foram consideradas pontos negativos da } \\
\text { atuação do IBAMA em Uruaçu, porém deve-se ressaltar que a responsabilidade pelo } \\
\text { monitoramento da qualidade da água do reservatório, bem como pelo licenciamento } \\
\text { ambiental da UHE Serra da Mesa é da superintendência do IBAMA de Goiânia-GO. }\end{array}$} \\
\hline 03 & $\begin{array}{l}\text { Sobre o lago estar ou não em Área de Preservação Ambiental: O } \\
\text { IBAMA informa que as margens num raio de 100m (de acordo } \\
\text { com a legislação) são consideradas APP (área de preservação } \\
\text { permanente) }\end{array}$ & & & PN \\
\hline 04 & $\begin{array}{l}\text { Sobre a existência de legislação específica aplicada ao lago o } \\
\text { IBAMA informa que não tem conhecimento de legislação } \\
\text { exclusiva para o lago, sugere que seja consultada a página da } \\
\text { Agência Ambiental do GO. }\end{array}$ & & & PN \\
\hline 05 & $\begin{array}{l}\text { Sobre a ocorrência de operações de fiscalização executadas no } \\
\text { lago Serra da Mesa, o IBAMA informa que constantemente são } \\
\text { realizadas operações de fiscalização no lago*. Para o ano de } \\
\text { 2011, de acordo com o Planejamento Anual, há operações de } \\
\text { fiscalização para serem executadas, especialmente em relação à } \\
\text { pesca. }\end{array}$ & $\mathbf{P}+$ & & \\
\hline \multicolumn{5}{|c|}{$\begin{array}{l}\text { OBS: Há fiscalização determinada pelo Estado, porém, não há dados sobre ocorrências de } \\
\text { operações de fiscalização realizadas pelo escritório regional do IBAMA em Uruaçu. }\end{array}$} \\
\hline 06 & $\begin{array}{l}\text { Sobre a quem compete à função fiscalizatória o IBAMA informa } \\
\text { que: A fiscalização se dá por meio dos seus servidores, em } \\
\text { especial, os agentes ambientais federais (fiscais nomeados por } \\
\text { portaria do presidente do IBAMA para realizar fiscalização } \\
\text { ambiental). Muitas vezes, as ações são feitas em parcerias com }\end{array}$ & & & PN \\
\hline
\end{tabular}




\begin{tabular}{|l|l|l|l|l|}
\hline & outros órgãos. & & \\
\hline 07 & $\begin{array}{l}\text { Sobre a forma de execução dessas operações o IBAMA informa } \\
\text { que em geral são realizadas por meio aquático e terrestre, com } \\
\text { servidores de diferentes localidades. }\end{array}$ & & PN \\
\hline
\end{tabular}

OBS: O processo de fiscalização é planejado no âmbito federal e estadual, e ocorre num mesmo período de tempo em todo território nacional*.

08 Em relação à freqüência dessas operações o IBAMA informa que: foi elaborado Planejamento de ações fiscalizatórias para 2011, mas, não se pode dizer com que freqüência será realizada em alguns casos por questões estratégicas de ação no combate às infrações ambientais*.

OBS: O IBAMA de Uruaçu não forneceu dados comprobatórios da freqüência das operações de fiscalização em Uruaçu*. Os dados foram fornecidos pelo IBAMA de Goiânia. Atribui-se ao fato das operações serem planejadas na esfera Federal e Estadual e por essa razão detêm o controle desses dados.

\begin{tabular}{|l|l|}
\hline 09 & Em relação à existência de medidas preventivas e/ou educativas \\
aplicadas pelo órgão na região de Uruaçu: As principais medidas \\
seriam a realização de atividades voltadas para a educação \\
ambiental, liderada pelo NEA (Núcleo de Educação Ambiental) \\
na superintendência*; exposição e atividades de conscientização \\
em eventos, e prestação de informações por meio do Linha \\
Verde (0800 61 8080) e diretamente no Escritório Regional de \\
Uruaçu.*
\end{tabular}

OBS: As atividades voltadas para a educação ambiental são realizadas na maioria das vezes na superintendência em Goiânia/GO*. Uruaçu, por ser o município de maior proximidade com o lago Serra da Mesa necessita de iniciativas referentes à educação ambiental que poderiam ser geradas e executadas pelo próprio escritório do IBAMA local*.

\begin{tabular}{|c|c|c|}
\hline 10 & $\begin{array}{l}\text { Em relação a medidas para reparar danos causados: O IBAMA } \\
\text { informa que a reparação dos danos, quando cabível, é uma } \\
\text { exigência obrigatória e incluída dentro do processo que é aberto } \\
\text { quando de uma autuação. Pode ser definida pela autoridade } \\
\text { julgadora ou, quando crime ambiental por um juiz. }\end{array}$ & $\mathbf{P N}$ \\
\hline 11 & Sobre fiscalização em relação à exploração turística no lago, a & $\mathbf{P N}$ \\
\hline
\end{tabular}




\begin{tabular}{|c|c|c|c|c|}
\hline & $\begin{array}{l}\text { existência de uma praia artificial criada na orla do lago em } \\
\text { Uruaçu, e a permanência de restaurantes flutuantes no local*, o } \\
\text { IBAMA fez algumas considerações: Nem todas as atividades } \\
\text { turísticas são realmente poluidoras*; os restaurantes flutuantes } \\
\text { são passíveis de adquirir licença para funcionar por serem de uso } \\
\text { público, destacando que nem todo aporte de resíduos e líquidos } \\
\text { em um corpo d’água podem ser considerados poluição*. }\end{array}$ & & & \\
\hline \multicolumn{5}{|c|}{$\begin{array}{l}\text { OBS: Se a atividade é passível de adquirir licença ela é legal, cabe ao IBAMA fiscalizar os } \\
\text { procedimentos da atividade em relação ao cumprimento de medidas visando evitar danos } \\
\text { ambientais. }\end{array}$} \\
\hline 12 & $\begin{array}{l}\text { Sobre a fiscalização em relação à pesca: O IBAMA informa que } \\
\text { no dia 04/02/2011 foi assinado um convênio de cooperação entre } \\
\text { IBAMA e ANEPE (Associação de Ecologia e Pesca Esportiva) } \\
\text { para o apoio em ações de fiscalização, atividades educativas e } \\
\text { pesquisa científica com o Tucunaré (espécie da ictiofauna }{ }^{6} \\
\text { presente no lago), a fim de subsidiar legislações futuras*. }\end{array}$ & $\mathbf{P}+$ & & \\
\hline \multicolumn{5}{|c|}{$\begin{array}{l}\text { OBS: O tucunaré é uma espécie de peixe bastante visado por pescadores. Portanto a } \\
\text { preocupação em preservar a espécie é de grande importância para a ictiofauna da região. }\end{array}$} \\
\hline 13 & $\begin{array}{l}\text { Em relação à ocupação para moradia na área que margeia o lago: } \\
\text { O IBAMA informa não ter informações a respeito. Apenas tem } \\
\text { conhecimento informalmente que o empreendedor FURNAS } \\
\text { Centrais Elétricas vem notificando todos os proprietários que } \\
\text { possuem construções em área irregular às margens do lago, para } \\
\text { que estas sejam retiradas. }\end{array}$ & & $\mathbf{P}_{-}$ & \\
\hline \multicolumn{5}{|c|}{$\begin{array}{l}\text { OBS: Estudos demonstram que todas as moradias muito próximas a recursos hídricos afetam } \\
\text { o meio ambiente de alguma forma, seja pelo lançamento de esgoto direto em suas águas, seja } \\
\text { pela construção de fossas sépticas, que contaminam o solo e conseqüentemente o lençol } \\
\text { freático na região, seja pelo lixo gerado sem destino apropriado, entre outras. Se a } \\
\text { fiscalização, o monitoramento e controle ambiental fazem parte das atribuições do IBAMA, o } \\
\text { escritório regional do IBAMA em Uruaçu tem participação nesta responsabilidade.. }\end{array}$} \\
\hline
\end{tabular}

Quadro 1 - Avaliação da Atuação do IBAMA/Uruaçu/GO: Pontos Positivos (P+), Pontos Negativos (P-), Pontos Neutros (PN)

\footnotetext{
${ }^{6}$ Designa-se ictiofauna ao conjunto das espécies de peixes que existem numa determinada região biogeográfica.
} 
Da avaliação dos dados nesta primeira etapa referente à atuação do Escritório Regional do IBAMA em Uruaçu, ocorreram (03) três pontos positivos e (04) quatro pontos negativos. Observa-se que os serviços prestados pelo Escritório Regional do IBAMA em Uruaçu, não satisfaz plenamente as necessidades do município.

Outros dados referentes a atuação do IBAMA na fiscalização foram adquiridos por meio de pesquisa na internet, de acordo com notícia divulgada em 23 de fevereiro de 2011, por Mirza Nóbrega da ASCOM/IBAMA/GO7, a "Operação CICHLA” (nome científico do Tucunaré), ocorreu entre os dias 10 e 19 de fevereiro de 2011, na região do Lago de Serra da Mesa, compreendendo os municípios de Niquelândia, Colinas e Uruaçu. O objetivo é disciplinar a pesca esportiva e coibir a pesca predatória no lago, principalmente no período de defeso/piracema, nesta operação foram aplicadas multas no valor de R\$ 14.600,00.

Segundo a mesma notícia, sob a coordenação do analista ambiental José Augusto Motta foi realizada a etapa aquática da operação, composta por sete agentes de fiscalização e de dois agentes da Polícia Federal, onde percorreram 600 km em água, realizando a apreensão de 01 barco; 02 motores; 02 armas de cano longo; 02 espingardas de mergulho; 01 freezer; 10 redes de malhas diversas; 35 pindas; 05 espinhéis e $180 \mathrm{~kg}$ de peixes, culminando com a retirada das águas de 100 embarcações de pesca esportiva sem licença e autuação de 02 pescadores profissionais. (MIRZA NÓBREGA, 2011)

Nas barreiras montadas em rodovias foram vistoriados 116 veículos, sendo que em 02 houve a apreensão de $25 \mathrm{~kg}$ de peixes e num terceiro uma rede de pesca. Nos bares e restaurantes flutuantes da orla do lago em Uruaçu os agentes apreenderam $400 \mathrm{~kg}$ de peixes de origem ilícita. Os pescados apreendidos foram doados para Asilos de Niquelândia e Uruaçu e também para a Ação Social de Uruaçu.

A segunda etapa da pesquisa de campo teve como participante do estudo uma Analista Ambiental da Superintendência do IBAMA/Goiânia/GO e serviu para complementar este estudo. Obteve-se os dados sobre licenciamento e qualidade da água demonstrados no quadro 2.

\begin{tabular}{|c|c|c|c|c|}
\hline & PESQUISA DE CAMPO - $2^{a}$ ETAPA & $\mathbf{P}+$ & $\mathbf{P}-$ & $\mathbf{P N}$ \\
\hline 01 & $\begin{array}{l}\text { Em relação à solicitação de dados que comprove a poluição da } \\
\text { água do lago da UHE Serra da Mesa o IBAMA de Goiânia }\end{array}$ & $\mathbf{P}+$ & & \\
\hline
\end{tabular}

\footnotetext{
${ }^{7}$ Assessoria de Comunicação do IBAMA
} 


\begin{tabular}{|c|c|c|c|}
\hline & $\begin{array}{l}\text { forneceu relatório do Programa de Monitoramento } \\
\text { Limnológico e da Qualidade da Água do Reservatório da } \\
\text { UHE Serra da Mesa, de } 2005 \text { a 2007. Documento elaborado } \\
\text { pela equipe da MULTIGEO Mineração, Geologia e Meio } \\
\text { Ambiente Ltda. contratada pela empresa empreendedora } \\
\text { FURNAS Centrais Elétricas. }\end{array}$ & & \\
\hline \multicolumn{4}{|c|}{ OBS: Dados do relatório comprovam a poluição da água do lago Serra da Mesa. } \\
\hline 02 & $\begin{array}{l}\text { Em relação ao Licenciamento Ambiental para funcionamento } \\
\text { da UHE Serra da Mesa o IBAMA de Goiânia informa que a } \\
\text { licença foi concedida à época pela Agência Ambiental de } \\
\text { Goiás, só passando para responsabilidade do IBAMA no ano } \\
\text { de 2005, já com a licença vencida. Hoje o IBAMA trabalha na } \\
\text { renovação dessa LO, para tal estabeleceu ao empreendedor } \\
\text { uma série de estudos que estão sendo analisados*. }\end{array}$ & $\mathbf{P +}$ & \\
\hline \multicolumn{4}{|c|}{$\begin{array}{l}\text { OBS: Consideram-se positiva a atuação do IBAMA em requerer do empreendedor da UHE } \\
\text { Serra da Mesa tais estudos. }\end{array}$} \\
\hline 03 & $\begin{array}{l}\text { Em relação à realização de novos estudos de impacto } \\
\text { ambiental desde a instalação da UHE Serra da Mesa o } \\
\text { IBAMA informa que os estudos ambientais anteriores ou } \\
\text { após a instalação de qualquer empreendimento, não é } \\
\text { competência do IBAMA. O órgão apenas de acordo com } \\
\text { determinação superior estabelece objetivamente as } \\
\text { providências de reparação e mitigação dos danos ambientais } \\
\text { decorrentes da instalação do empreendimento, analisa, e } \\
\text { emite parecer, em função das medidas estarem sendo } \\
\text { cumpridas, dentro dos padrões e prazos determinados }\end{array}$ & & PN \\
\hline 04 & $\begin{array}{l}\text { Em relação a estudos sobre a poluição do lago praticados } \\
\text { pelo IBAMA o órgão informa que esse tipo de estudo é } \\
\text { realizado por empresas contratadas pelos empreendedores. } \\
\text { Informa que recentemente pediu estudos sobre os níveis de } \\
\text { mercúrio na água do lago e também no pescado*. }\end{array}$ & $\mathbf{P}+$ & \\
\hline \multicolumn{4}{|c|}{ OBS: Atuação positiva de acordo com sua atribuição. } \\
\hline 05 & Em relação à legislação específica aplicada ao lago o & & PN \\
\hline
\end{tabular}




\begin{tabular}{|l|l|l|l|l|}
\hline & $\begin{array}{l}\text { IBAMA informa que não há. Aplica-se ao lago a mesma } \\
\text { legislação ambiental vigente no país. }\end{array}$ & & & \\
\hline 06 & $\begin{array}{l}\text { Sobre a existência de medidas preventivas e/ou educativas } \\
\text { em relação à poluição ambiental na região do lago o IBAMA } \\
\text { informa que o trabalho que será feito nesse sentido faz parte } \\
\text { do Plano de Comunicação Social e Educação Ambiental que } \\
\text { está dentro das exigências que deverão ser implementadas } \\
\text { por FURNAS. }\end{array}$ & P+ & & \\
\hline
\end{tabular}

Quadro 2 - Avaliação da Atuação do IBAMA/GO referente ao Licenciamento da UHE Serra da Mesa, e, Monitoramento da Poluição da água do reservatório.

Da avaliação dos dados nesta segunda etapa, referente à atuação do IBAMA no Licenciamento da UHE Serra da Mesa, e, Monitoramento da Poluição da água do reservatório, observa-se a ocorrência de (04) quatro Pontos Positivos, não ocorreram Pontos Negativos, considerando-se satisfatória a atuação do IBAMA neste quesito.

O IBAMA emitiu Nota Técnica após a constatação da necessidade de se estabelecer ao empreendedor Eletrobrás Furnas uma série de medidas a serem implementadas, medidas estas que vão desde a retomada de ações de monitoramento e de programas ao estabelecimento do planejamento para desmobilização de edificações construídas por terceiros nas áreas pertencentes à Furnas e desmate das áreas a serem inundadas.

O cumprimento de tais medidas serviria de diretrizes para a renovação da Licença de Operação da UHE Serra da Mesa. Essas medidas constam na NOTA TÉCNICA No 10/2010COLIC/DGPA/IBAMA-GO, em anexo a este trabalho. (ANEXO B)

Ressalte-se que esta nota técnica foi elaborada por Analistas Ambientais do IBAMA à consideração superior, em 15 de setembro de 2010, e, algumas medidas deveriam ser implementadas no prazo de 45 dias, outras no prazo de 90 dias, outras em até 365 dias, porém não se tem dados do andamento dessas medidas.

Conforme dados coletados no IBAMA, no ano de 2005 foi proferida Decisão Judicial remetendo ao IBAMA o Licenciamento Ambiental da UHE Serra da Mesa, antes sob responsabilidade do Estado.

Foi exigida da empresa empreendedora uma série de estudos que estão em análise. De acordo com o PARECER TÉCNICO No 20/2010-COLIC/DGPA/IBAMA-GO (ANEXO B), foram analisados uma série de documentos encaminhados pela Eletrobrás Furnas em atendimento ao Ofício/IBAMA-GO/DGPA No 758/2010. 
Os documentos analisados pelo IBAMA neste trabalho foram os seguintes:

\section{a) Plano de Monitoramento das Concentrações de Mercúrio em Diversos Compartimentos Biogeoquímicos do Reservatório da UHE Serra da Mesa}

O plano de trabalho apresentado pelo empreendedor tem como objetivo demonstrar passo a passo, as ações necessárias para a análise das concentrações de mercúrio no ambiente e nos organismos representados de diversos níveis da cadeia alimentar local no reservatório da UHE Serra da Mesa. Serão coletadas amostras, semestralmente, num período de cinco anos, em 16 pontos definidos, onde serão amostradas até 15 espécies de ictiofauna, fitoplâncton e zooplâncton, e amostras de sedimentos de regiões lóticas e lêntica, além de material em suspensão em todos os pontos de coleta. Será gerado relatório conclusivo com os resultados de todas as análises das concentrações de mercúrio em cada compartimento biogeoquímico do reservatório.

\section{b) Plano de Demarcação da Cota de Desapropriação do Reservatório da UHE}

\section{Serra da Mesa}

O plano apresentado tem por objetivo estabelecer procedimentos para a demarcação da cota de desapropriação da UHE Serra da Mesa e preservação da área patrimonial da empresa. Serão demarcados os limites da área de concessão do entorno do reservatório para conhecimento dos interessados, demarcando a área inundável e para impedir o uso e ocupação irregular.

\section{c) Plano Geral de Desmatamento da UHE Serra da Mesa}

O plano de desmatamento apresentado dá continuidade ao trabalho proposto em 1996 por um grupo composto por FURNAS, FEMAGO e IBAMA, onde foi planejado a retirada prévia e aproveitamento dos recursos florestais na área do reservatório. Cujo objetivo era selecionar as áreas prioritárias para desmatamento considerando a qualidade da água, controle de vetores, aproveitamento econômico da matéria prima florestal, fauna terrestre e aquática e uso múltiplo do reservatório.

A Proposta Geral de Desmatamento indicava um trecho prioritário e um trecho de Desmatamento Recomendado. O trecho prioritário ficaria a cargo de FURNAS e 
compreenderia o desmatamento integral da área imediatamente a montante da barragem e entre as cotas 440 e 460m.. E o trecho de Desmatamento Recomendado seria aberto a interessados no aproveitamento econômico da madeira compreendendo a faixa abaixo da cota 440m. Com base nesse planejamento FURNAS requereu em 1996 autorização de desmatamento global para toda a área da UHE Serra da Mesa e esta foi concedida pelo IBAMA e pela FEMAGO sem data de validade.

Em vistas à retomada do enchimento do reservatório da UHE Serra da Mesa, segundo recomendação do Ordenador Nacional do Sistema (ONS), FURNAS informa que foram identificados 2.992 fragmentos remanescentes de vegetação entre a cota atual e a cota 460, o que somaria 11.200 ha. Porém a proposta de FURNAS é desmatar apenas o que foi previsto em 1996, correspondente a 180 ha deste montante. Considerando que a não retirada da madeira inundável da área compreendida entre as cotas 440 e 460 da UHE Serra da Mesa, mesmo que sua permanência não traga grandes modificações na qualidade da água do reservatório, deverá ser providenciado o desmatamento levando em conta o aproveitamento da madeira que será submersa. Priorizando as áreas que serão submersas primeiro.

\section{d) Levantamento das Cavidades Naturais}

De acordo com o levantamento foram reconhecidas mais de 150 ocorrências de estruturas cársticas $^{8}$, entre grutas, cavernas, dolinas e abismos, nos municípios de Colinas do Sul, Uruaçu, Niquelândia, Santa Rita do Novo Destino, Campinaçu, e Minaçu, das quais 15 (quinze) foram consideradas de interesse por se localizarem nas proximidades da zona influenciada pelo enchimento completo do reservatório. Como exemplo, essas cavernas geralmente são habitat de morcegos que podem causar a Raiva Animal, o relatório sugere um Plano de Monitoramento e Combate a esta doença.

\section{e) Plano de Comunicação Social e Educação Ambiental}

Este Plano visa atender as solicitações referentes às questões tais como: informações pertinentes à localização e abrangência do reservatório da UHE Serra da Mesa, a importância

\footnotetext{
8 Tipo de relevo geológico caracterizado pela dissolução química (corrosão) das rochas, que leva ao aparecimento de uma série de características físicas, tais como cavernas, dolinas, vales secos, vales cegos, cones cársticos, rios subterrâneos, canhões fluviocársicos, paredões rochosos expostos e lapiás. O relevo cárstico ocorre predominantemente em terrenos constituídos de rocha calcária, mas também pode ocorrer em outros tipos de rochas carbonáticas, como o mármore e rochas dolomíticas.
} 
da Usina para o abastecimento energético de Goiás e do Distrito Federal, informações referentes a variação dos níveis do reservatório, riscos de ocupações irregulares, conservação das Áreas de Preservação Permanente, legislação ambiental, espécies em extinção, entre outras.

O público alvo foi definido em: ocupantes irregulares, população lindeira ${ }^{9}$ ao reservatório (área diretamente afetada), associações representativas da população e líderes comunitários, escolas, universidades, ONGs, entre outros.

O plano prevê a elaboração de materiais informativos para apoio às atividades desenvolvidas no campo, tais como, folder, cartazes, cartilhas, palestras, entre outras.

Devido à especificidade do tema relativo ao mercúrio, pretende-se gerar um debate direcionado aos especialistas das áreas de saúde e meio ambiente de todos os municípios presentes na área de influência da UHE Serra da Mesa.

\section{f) Levantamento das Áreas Protegidas no Entorno do Reservatório}

O objetivo do levantamento é identificar as Unidades de Conservação existentes nas regiões próximas ao reservatório, incluindo Áreas de Proteção Ambiental, Áreas de Preservação Permanente, Reservas Indígenas, RPPNs e Parques Nacionais e áreas Prioritárias para Conservação da Biodiversidade.

O levantamento foi feito a partir de dados secundários e levantamento de informações existentes em órgãos municipais, estaduais e federais, especialmente prefeituras, Sistema Estadual de Estatística e Informações Geográficas de Goiás e do Ministério do Meio Ambiente.

\section{g) Plano de Monitoramento do Lençol Freático}

De acordo com o parecer, o principal objetivo do programa é o monitoramento do aqüífero freático na Área de Influência Direta (AID) e do seu entorno imediato nas áreas susceptíveis à elevação do nível freático. E explica que na formação de lagos artificiais a elevação e o rebaixamento do nível das águas promovem uma nova pressão que atua sobre as nascentes, que conseqüentemente leva a uma subida generalizada do nível das águas subterrâneas para uma nova posição. Como está previsto o enchimento do reservatório da

\footnotetext{
${ }^{9}$ Relativo à limite, limítrofe (Fonte: www.wikepedia.org.wike).
} 
UHE Serra da Mesa já para o ano de 2011, o IBAMA determina que os trabalhos sejam iniciados imediatamente.

Da avaliação dos dados nesta segunda etapa, uma consideração merece ser feita em relação a atuação do IBAMA no processo de renovação da licença de operação (LO) da UHE Serra da Mesa. Desde a transição do licenciamento para o IBAMA no ano de 2005, data em que a usina já funcionava com a licença vencida, somente em 2010 o IBAMA retoma o trabalho para renovação dessa licença.

Destacando que as ações praticadas pelo IBAMA e abordadas neste estudo fazem parte das ações que o IBAMA deve desenvolver no cumprimento de suas atribuições, como, a proposição e edição de normas e padrões de qualidade ambiental para empreendimentos considerados potencialmente poluidores. Dessa forma, avalia-se de maneira satisfatória a atuação do IBAMA, neste quesito.

A terceira etapa da pesquisa de campo teve como participante do estudo uma Técnica do Departamento de Fiscalização da Superintendência do IBAMA/Goiânia/GO, onde se obteve informações que complementam os dados da primeira etapa da pesquisa, sobre as ações de fiscalização do IBAMA. Serão demonstradas no quadro 3.

\begin{tabular}{|l|l|l|l|l|}
\hline & PESQUISA DE CAMPO - 3 ${ }^{\text {ETAPA }}$ & P+ & P- & PN \\
\hline 01 & $\begin{array}{l}\text { O IBAMA informa que as operações de fiscalização quando } \\
\text { programadas saem dos Estados para os municípios e recebem } \\
\text { apoio dos órgãos regionais e de outros órgãos se necessário. } \\
\text { No reservatório o problema maior é em relação a pesca } \\
\text { predatória para fins comerciais. }\end{array}$ & P+ & & \\
\hline OBS: A fiscalização ocorre geralmente em época de defeso (piracema), mas a pesca \\
\hline 02 & $\begin{array}{l}\text { Em relação a dados quantitativos de controle através de } \\
\text { fiscalização e aplicação de penalidades na região não foi } \\
\text { fornecido dados diretamente no órgão sob a alegação desses } \\
\text { dados não estarem disponíveis para consulta no sistema, } \\
\text { estes precisariam ser gerados por uma chefia a qual não se } \\
\text { conseguiu acesso imediato. Tais dados foram fornecidos } \\
\text { posteriormente via e-mail. }\end{array}$ & Pçante todo o ano. & & \\
\hline 03 & Em relação a fiscalização das ocupações irregulares na área & P+ & & \\
\hline
\end{tabular}




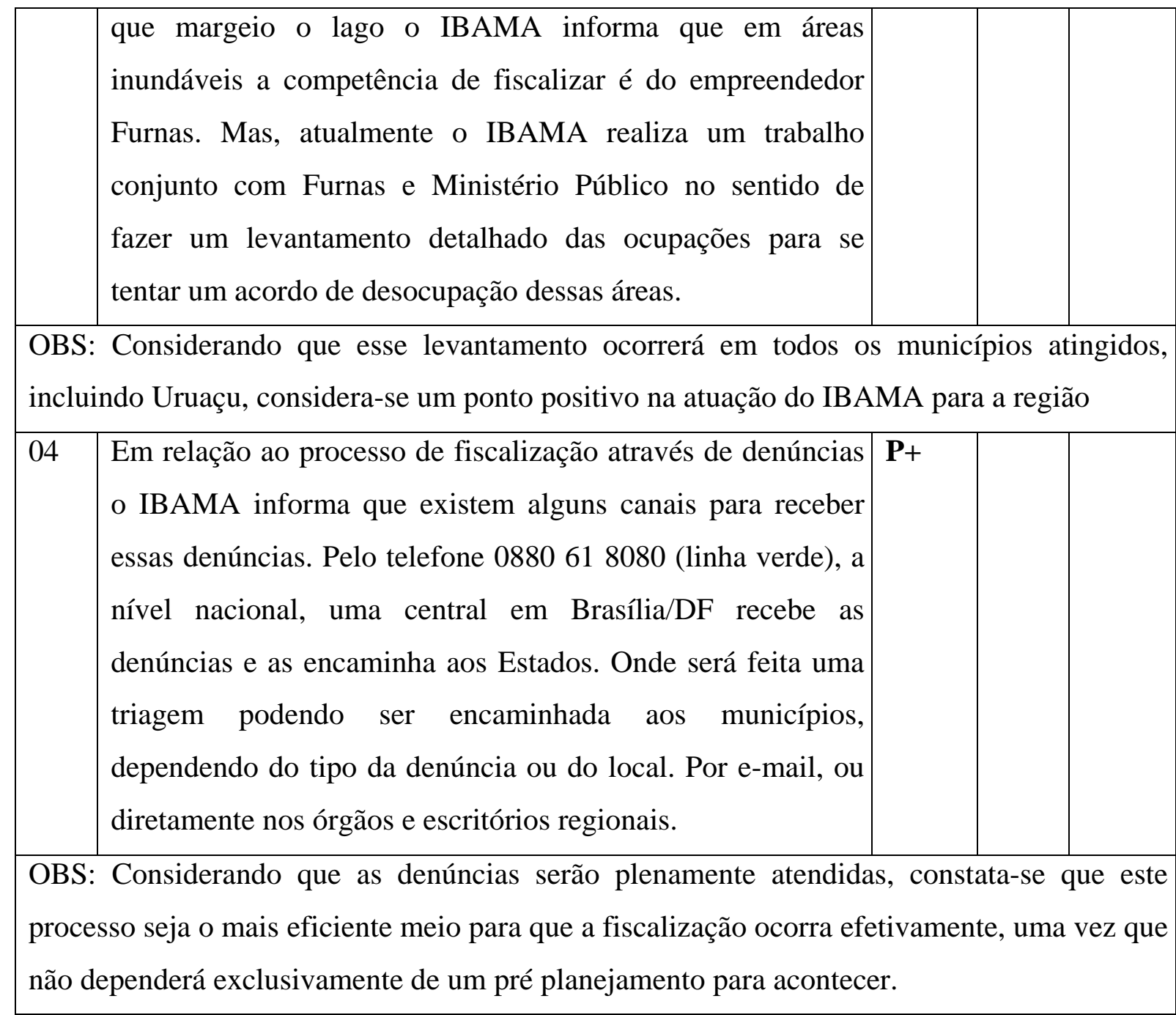
Quadro 3. Avaliação da Atuação do IBAMA/GO referente à Fiscalização

Da avaliação dos dados nesta terceira etapa, referente à atuação do IBAMA na fiscalização de infrações, observa-se a ocorrência de (04) quatro Pontos Positivos, considerando-se satisfatória a atuação do IBAMA/Goiânia/GO neste quesito.

Em busca de informações mais precisas sobre as ações de fiscalização do IBAMA na região estudada, serão abordados aqui, dados fornecidos pelo IBAMA de Goiânia/GO. São relatórios de autos de infração lavrados por municípios, e encontram-se em anexo a este estudo. (ANEXOS - D e E).

Os referidos relatórios apresentam autos lavrados nos anos de 2009 e 2010.

O relatório do ano 2009 (ANEXO D), apresentam 88 autos lavrados, distribuídos nos municípios de Niquelândia (32), Minaçu (25), Campinaçu (15), Campinorte (09), Colinas do Sul (01), e Uruaçu (06). Dos seis autos lavrados em Uruaçu, dois foram na área de fauna, dois na área de flora, e dois na área de pesca. 
O relatório do ano 2010 (ANEXO E), apresentam apenas 15 autos lavrados por municípios, Niquelândia (02), Minaçu (05), Campinorte (02) e Uruaçu (06). Também foram lavrados seis autos no município de Uruaçu, todos na área de flora.

Comparando-se os relatórios do ano 2009 e 2010 observa-se uma redução significativa na quantidade de autos lavrados de um ano para o outro, que segundo o IBAMA se deve ao trabalho que vem realizando em conscientização e educação ambiental. Trabalho este realizado pelo Núcleo de Educação Ambiental da Superintendência e levado aos municípios através das Secretarias de Meio Ambiente. Segundo o IBAMA essas secretarias vêm sendo instaladas nesse período em que ocorreram as reduções, o que demonstra que a meta de deixar de ser um órgão autuador, para ser educador está sendo cumprida ${ }^{10}$. (Informação Verbal).

Para uma melhor visualização o quadro 3.1 apresenta os autos de infração lavrados por município na região da UHE Serra da Mesa, no ano 2009.

\begin{tabular}{|l|l|l|}
\hline \multicolumn{4}{|c|}{ AUTOS DE INFRAÇÃO LAVRADOS POR MUNICÍPIO/UHE SERRA DA } \\
MESA/GO/ANO 2009 \\
\hline Município & Quantidade Infração & Tipo Infração \\
\hline Campinaçu & 15 Autos lavrados & Pesca e Flora \\
\hline Campinorte & 09 Autos lavrados & Flora e Controle Ambiental \\
\hline Colinas do Sul & 01 Auto lavrado & Pesca \\
\hline Minaçu & 25 Autos lavrados & $\begin{array}{l}\text { Flora e Cadastro Técnico } \\
\text { Federal }\end{array}$ \\
\hline Niquelândia & 32 Autos lavrados & $\begin{array}{l}\text { Pesca, Flora, Fauna, e } \\
\text { Controle Ambiental }\end{array}$ \\
\hline Uruaçu & & Pesca, Flora e Fauna \\
\hline
\end{tabular}

Fonte: IBAM/GO - Adaptada pelo autor

O quadro 3.2 apresenta os autos de infração lavrados por município na região da UHE Serra da Mesa, no ano 2010.

\footnotetext{
${ }^{10}$ Informação verbal prestada por José Carlos Bispo dos Santos, Agente de Fiscalização do IBAMA/Goiânia.
} 


\begin{tabular}{|l|l|l|}
\hline \multicolumn{3}{|c|}{ AUTOS DE INFRAÇÃO LAVRADOS POR MUNICÍPIO/UHE SERRA DA } \\
MESA/GO/ANO 2010 \\
\hline Município & Quantidade Infração & Tipo Infração \\
\hline Campinaçu & 00 & \\
\hline Campinorte & 02 Autos lavrados & Flora \\
\hline Colinas do Sul & 00 & $\begin{array}{l}\text { Pesca, Flora e Controle } \\
\text { Ambiental }\end{array}$ \\
\hline Minaçu & 05 Autos lavrados & Flora \\
\hline Niquelândia & 02 Autos lavrados & Flora \\
\hline Uruaçu & 06 Autos lavrados & \\
\hline
\end{tabular}

Fonte: IBAMA/GO - Adaptada pelo autor

Seguem comentários conclusivos referentes à atuação do IBAMA no quesito Fiscalização na região alvo do estudo:

Comparando os dados apresentados para todos os municípios da região nos exercícios 2009 e 2010, observa-se que houve uma redução significativa das infrações ocorridas de um exercício para o outro, menos no município de Uruaçu, que permaneceu com a mesma quantidade de autos de infração lavrados.

Observa-se que a maioria dos índices teve uma redução de ocorrências, dessa forma, considera-se satisfatória a atuação do IBAMA/GO na região. Constatando-se que a fiscalização do IBAMA tem sido eficiente apresentando bons resultados onde foi praticada.

Apenas uma observação merece reflexão nesta avaliação, a observância de que no município de Uruaçu os índices permaneceram, e as causas para este fato não ficaram explícitas neste estudo. 


\title{
5. CONCLUSÕES E RECOMENDAÇÕES
}

A falta de preservação dos recursos hídricos da terra continua a ser um fator bastante preocupante nos dias atuais, fato que deu origem à escolha do tema deste trabalho, principalmente pela preocupação com a possibilidade de contaminação da água do lago Serra da Mesa. O município de Uruaçu mereceu destaque neste estudo por ter acesso direto ao lago e ser um ponto turístico bastante visitado para lazer.

O problema gerou a necessidade de investigar a situação, de avaliar a atuação do principal órgão fiscalizador da poluição/degradação ambiental em âmbito federal, o Instituto Brasileiro do Meio Ambiente e dos Recursos Naturais Renováveis, IBAMA.

Nesse sentido buscou-se compreender melhor o conceito de responsabilidade social, e os benefícios que o conceito de responsabilidade social traz à nova gestão pública para atender adequadamente a sociedade.

No trato da administração pública Matias Pereira afirma que:

\begin{abstract}
A percepção de que é preciso melhorar o desempenho da gestão pública é cada vez mais evidente no Brasil. A administração pública na atualidade, que tem como referência o modelo de gestão privada, não pode desconsiderar que o setor privado busca o lucro e a administração pública visa realizar sua função social. Esta função Social deve ser alcançada com a maior qualidade possível na sua prestação de serviços, ou seja, sendo realizada de forma eficiente, eficaz e efetiva. (MATIAS PEREIRA 2007, p. 25).
\end{abstract}

Este conceito fundamenta a realização deste estudo no sentido de verificar se a prestação dos serviços do IBAMA está atendendo as necessidades do município de Uruaçu.

Para realizar a pesquisa de campo foi escolhido o método qualitativo de estudo, usando a entrevista semi estruturada como técnica de coleta dos dados. Além da pesquisa de campo os dados também foram coletados via internet, e em pesquisa no sitio do órgão. A apresentação dos dados se deu de forma manual, os dados foram analisados através da observação e comparação de pontos considerados negativos e positivos da atuação do órgão, bem como pela análise de documentos.

O caminho percorrido para se chegar aos resultados encontrados se deu inicialmente em constatar a poluição/contaminação da água do reservatório da UHE Serra da Mesa. Em seguida procurou-se saber da existência de legislação específica aplicada ao lago Serra da Mesa, a identificação de instrumentos de políticas ambientai existentes e suas aplicações, e, para concluir verificar a atuação do IBAMA como principal órgão fiscalizador das questões referentes ao meio ambiente. 
A pesquisa de campo foi dividida em três etapas devido a carência de informações para uma avaliação da atuação do órgão no local delimitado para o estudo. A primeira etapa foi realizada no IBAMA municipal, em Uruaçu/GO, e, as outras duas etapas na sede do IBAMA em Goiânia/GO.

A primeira constatação proposta neste estudo foi a comprovação da poluição da água do reservatório, suas causas e conseqüências, cujo objetivo foi cumprido satisfatoriamente. $\mathrm{O}$ IBAMA de Goiânia forneceu cópias de documentos internos referentes a estudos realizados por laboratórios especializados em estudos da qualidade da água. Desses documentos pode-se comprovar a contaminação da água por alguns agentes poluidores, tais documentos constam em anexo ao presente estudo.

Em relação ao Licenciamento Ambiental da UHE serra da mesa, cuja atribuição é do IBAMA desde 2005, especificamente da Superintendência/IBAMA/GO, foi constatado neste aspecto que o órgão vem cumprindo seu papel determinando e fiscalizando a implementação das medidas cabíveis para a renovação da LO do empreendimento.

Considerando as ações do escritório regional do IBAMA em Uruaçu/GO aqui apresentadas, destacam-se algumas informações relevantes para a avaliação da sua atuação no município de Uruaçu. Nesta pesquisa constatou-se que a atuação do IBAMA no município de Uruaçu não possui uma efetividade de acordo com as necessidades locais, lembrando que parte do município é banhada pela água do lago Serra da Mesa.

Para essa constatação atribui-se um ponto observado na atuação do órgão referente à fiscalização, foi o fato das operações de fiscalização ser planejadas em âmbito federal, e serem concretizadas num mesmo período em todo o território nacional. Atribui-se também o reduzido contingente de funcionários do Escritório Regional do IBAMA local, segundo o chefe responsável pelo órgão são apenas cinco funcionários, o próprio chefe, um chefe substituto e três agentes ambientais (fiscais).

Outro fator observado na região é que as comunidades ribeirinhas não têm a consciência da importância da preservação dos recursos hídricos daquela região. De onde se observa a necessidade de programas de educação ambiental de uma forma mais contínua e duradoura

O IBAMA na esfera Estadual está fazendo sua parte em relação ao controle e monitoramento da qualidade da água do reservatório, determinando ao empreendedor da UHE Serra da Mesa os estudos necessários. Porém, este estudo evidencia que medidas precisam ser tomadas no sentido de maior proteção aos recursos hídricos na região de Uruaçu, devido às suas características específicas de cidade turística. Acredita-se que somente através de um 
processo de fiscalização contínuo poderá se prevenir e constatar as irregularidades causadoras de danos ambientais na região.

Em relação ao fato da não redução dos autos de infrações lavrados no município de Uruaçu, não ficaram explícitas as causas neste estudo, fica evidente a necessidade de um estudo mais profundo nesta questão.

Uma sugestão como medida mitigatória para os problemas ambientais ocorridos no município de Uruaçu seria o investimento contínuo em práticas de educação ambiental. Como planejar eventos direcionados para a educação ambiental, planejados e ministrados pelo próprio órgão regional, pois o nome da instituição causaria um impacto bastante positivo.

Dentro das limitações do tempo deste trabalho fica a sugestão de continuidade deste para um futuro estudo. Destacando sua relevância para o reconhecimento de como o meio ambiente está suscetível das ações predatórias da degradação dos recursos naturais da região do lago Serra da Mesa. 


\section{REFERÊNCIAS}

ADORNO JÚNIOR, U. F. A influência da Responsabilidade Social Empresarial no Setor

Público. João Pessoa - $\mathrm{PB}, 09$ ago. 2010. Disponível em: http://www.administradores.com.br/informe-se/artigos/a-influencia-da-responsabilidadesocial-empresarial-no-setor-publico/47145/. Acesso em: 10 nov. 2010.

BRANDÃO, H. J. ; PALASSI, M. P.; FERREIRA, D. N. A. Administração Pública. Apostila elaborada para o curso de administração na modalidade à distância. Brasília: UnB, 2007.

GOIÂNIA. Instituto Brasileiro do Meio Ambiente e dos Recursos Naturais Renováveis IBAMA. PARECER TÉCNICO No 20/2010-COLIC/DGPA/IBAMA/GO. Plano de Comunicação Social e Educação Ambiental, Plano de Demarcação da Cota de Desapropriação do Reservatório, Plano de Monitoramento das Concentrações de Mercúrio em Diversos Compartimentos Biogeoquímicos do Reservatório, Levantamento das Cavidades Naturais, Goiânia/GO, dezembro 2010, 14 p.

GOIÂNIA. Instituto Brasileiro do Meio Ambiente e dos Recursos Naturais Renováveis IBAMA. NOTA TÉCNICA No 10/2010-COLIC/DGPA/IBAMA-GO. Processo 02010.004106/2004-21 - UHE Serra da Mesa. 3 p.

GOIÂNIA. Instituto Brasileiro do Meio Ambiente e dos Recursos Naturais Renováveis IBAMA. Plano Diretor de Tecnologia da Informação (PDTI) IBAMA, $2^{a}$ Ed., 2010/2011, Centro Nacional de Telemática, Brasília, 2010. Disponível em: <http: //www.ibama.gov.br/index.php>, Acesso em: Jan. 2011.

INSTITUTO SERRANO NEVES, Laboratório revela contaminação no lago da usina da Serra da Mesa, Jornal cidade, Uruaçu - Goiás, 24 de maio 2009, Disponível em: $<$ http://www.jotacidade.com/noticias/exibir.php?noticia_id=193\&noticia_link=1>, Acesso em: Set. 2010.

INSTITUTO SERRANO NEVES, Projeto Amigos do Lago Serra da Mesa, Disponível em: http://www.serrano.neves.nom.br/lsm/aguadoce/alerta_serradamesa.htm, Acesso em: Dez. 2010.

MATIAS-PEREIRA, J. Manual de Gestão Pública Contemporânea. São Paulo, Ed. Atlas, 2007. 
MULTIGEO. Boletim Técnico do Programa de Monitoramento Limnológico e da Qualidade da Água do Reservatório da UHE - Serra da Mesa, 16 ${ }^{\mathrm{a}}$ Campanha - Fevereiro 2007, Minaçu/GO, 28 p. (REL.TEC./MULTIGEO/07063).

MULTIGEO. Programa de Monitoramento Limnológico e da Qualidade da Água do Reservatório da UHE - Serra da Mesa, MULTIGEO, Mineração, Geologia e Meio Ambiente Ltda, Relatório Final - 2005 a 2007, Minaçu/GO, 169 p. (REL.TEC./MULTIGEO/07066).

NASCIMENTO, L. F. Gestão Ambiental e Sustentabilidade. Apostila elaborada para o curso de administração na modalidade à distância. Brasília: UnB, 2008.

NÓBREGA, Mirza. Ibama conclui as Operações Rios Federais I e Cichla em Goiás. ASCOM/IBAMA/GO. Goiânia, 2011. Disponível em: <http://www.ibama.gov.br/archives/14605>. Acesso em: 28 fev. 2011.

PINHEIRO, Sinvaline, Serra da Mesa Apresenta Problemas com Poluição. Jornal Diário do Norte, Uruaçu - Goiás, 22 fev. 2009. Disponível em:<www.jornaldiariodonorte.com.br $>$. Acesso em: 25 set. 2010.

SOUZA, W. J. Responsabilidade Social Corporativa e Terceiro Setor. Apostila elaborada para o curso de administração na modalidade à distância. Brasília: UnB, 2008.

VARELA, C. A. Instrumentos de Políticas Ambientais, Casos de Aplicação e seus Impactos para as empresas e a sociedade. Rev. Ciênc. Admin. p. 251-262, Dez. 2008, Disponível em: <http://engema.up.edu.br/arquivos/engema/pdf/PAP0330.pdf> Acesso em: 28 set. 2010.

WIKIPÉDIA. A Enciclopédia Livre. Disponível em: http://pt.wikipedia.org/wiki/Special:Search?search=\&go=Go

ZANELLA, L. C. H. Metodologia da pesquisa. Apostila elaborada para o curso de administração na modalidade à distância. Brasília: UnB, 2009. 


\section{APÊNDICE A - Carta Apresentação}

Prezado (a) Senhor (a),

Meu nome é Neusa Kiyotsuka Gomes, sou aluna do curso de Graduação em Administração na modalidade à distância, pela UnB. Estou realizando uma pesquisa sobre a poluição das águas do Lago Serra da Mesa, o estudo servirá para elaboração da minha monografia.

O objetivo das informações coletadas será exclusivamente de fornecer dados para uma análise da atuação do IBAMA como órgão fiscalizador em relação à poluição do Lago de Serra da Mesa. Caso você concorde, você deverá participar de uma entrevista que será previamente agendada e desde já adianto que sua privacidade será mantida em todas as discussões sobre os dados desse estudo. Será garantido o anonimato quanto à identidade do entrevistado.

Solicito sua colaboração como participante de uma entrevista que preciso realizar para obter maiores informações à cerca do tema de minha pesquisa. Caso concorde agendaremos uma data para a realização da entrevista.

Mais informações a meu respeito podem ser encontradas na secretaria do CEADUnB, por meio do telefone (61) 3307-2343 R. 204, minha turma é a K, e, minha matrícula 0713201. Você também pode me ligar para confirmar o teor desta pesquisa ou tirar qualquer dúvida no telefone (61) 3467-6295. Ou ainda pelo e-mail: neusa_nkg@yahoo.com.br

Conto com sua colaboração, aguardo sua resposta,

Atenciosamente,

Neusa Kiyotsuka Gomes 


\section{APÊNDICE B - Termo de Consentimento Informado}

\section{Por favor, leia atentamente o termo de consentimento abaixo:}

TÍTULO DO ESTUDO: Responsabilidade e Desempenho do IBAMA em relação à Poluição do Lago de Serra da Mesa.

RESPONSÁVEL PELA PESQUISA: Neusa Kiyotsuka Gomes

DESCRIÇÃO: Você está convidado a participar de uma pesquisa sobre Gestão Ambiental e Responsabilidade Social Corporativa. O objetivo das informações coletadas é exclusivamente de fornecer dados para uma análise da atuação do IBAMA como órgão fiscalizador em relação à poluição do Lago de Serra da Mesa. Caso você concorde, você deverá participar de uma entrevista que será previamente agendada.

RISCOS E BENEFÍCIOS: Não existem riscos associados a este estudo. Não existem benefícios pessoais a partir deste estudo, exceto que esta pode vir a ser uma experiência agradável e que você pode colaborar para pesquisas acadêmicas.

TEMPO DE PARTICIPAÇÃO: A entrevista levará entre 30 a 40 minutos para ser realizada e este, será o tempo que você necessitará para participar desta pesquisa.

DIREITOS DO SUJEITO PARTICIPANTE: se você leu este formulário e decidiu participar desta pesquisa, por favor, compreenda que a sua participação é voluntária e você tem o direito de retirar o seu consentimento ou desistir de participar a qualquer momento sem penalidades. Você tem o direito de se recusar a responder às perguntas. Sua privacidade será mantida em todas as discussões sobre os dados desse estudo.

INFORMAÇÕES PARA CONTATO: se você tiver qualquer dúvida sobre este estudo, os seus procedimentos, riscos e benefícios ou sobre as formas de tratamento de dados você poderá entrar em contato comigo pelo e-mail: www.neusa_nkg@yahoo.com.br. Se você não estiver de acordo com a maneira de realização deste estudo, se tiver dúvidas, reclamações ou questões gerais sobre a investigação ou ainda sobre seus direitos como um sujeito da pesquisa, entre em contato comigo.

Atenciosamente, 


\section{APÊNDICE C - Pesquisa de Campo - $1^{\text {a }}$ Etapa}

\section{Roteiro da entrevista realizada com o chefe do escritório regional do IBAMA na cidade de Uruaçu-GO}

O problema alvo do estudo é a poluição do Lago Serra da Mesa, suas causas e conseqüências, e a atuação do IBAMA em relação a essa poluição;

1. A poluição do Lago é visível em vários locais onde visitei, assim surgiu o interesse desta pesquisa. Inicialmente realizei uma pesquisa na internet onde constatei a poluição do Lago por vários agentes poluidores, além do lixo que se encontra às suas margens. Dentre eles, proliferação de algas tóxicas (Cianobactérias), mercúrio, alumínio, ferro e fosfato. Para responder a questão da minha pesquisa preciso de dados que comprovem a poluição do Lago de Serra da Mesa. Teria algum documento que eu posso ter acesso? Documentos como gráficos, tabelas e relatórios?

No IBAMA, aqui, não temos nenhum documento a que se refere, especialmente por não trabalharmos quase nada com pesquisa. Se há algum relatório sobre vistoria, autuação, etc. de poluição no lago, não tenho conhecimento.

O que eu posso te sugerir é consultar o NLA (Núcleo de Licenciamento Ambiental) do IBAMA (em Goiânia), para saber como obter uma cópia do licenciamento da UHE Serra da Mesa. Falo isso porque todo licenciamento deste tipo tem estudos prévios e posteriores ao represamento sobre diversos aspectos, incluindo qualidade da água. Especialmente o EIA (Estudo de Impacto Ambiental) deve conter estas informações de que precisa. Posso te conseguir o número do NLA, depois.

2. Os principais objetivos institucionais do IBAMA são relativos ao licenciamento ambiental, à autorização de uso dos recursos naturais, à fiscalização, monitoramento e controle ambiental. No processo do licenciamento ambiental, é verificada a viabilidade ou não de localização e implementação do empreendimento. Uma vez considerado viável, inicia-se o processo de licenciamento ambiental, onde serão emitidas três licenças: LP (Licença Prévia), LI (Licença Instalação) e LO (Licença de Operação). No caso das grandes obras a serem implementadas, 
como a UHE de Serra da Mesa, essas licenças foram realizadas? E quanto aos EIAs, continuam sendo feitos novos estudos de impacto ambiental?

Apesar da legislação sobre licenciamento ser mais recente, certamente o empreendimento da UHE obteve as licenças. No entanto, informações mais detalhadas podem ser obtidas também no NLA. Posso confirmar depois se o licenciamento foi realizado pelo IBAMA ou órgão estadual de meio ambiente, pois também é competência deste órgão o licenciamento, quando dentro do estado.

3. O Lago está em Área de Preservação Ambiental?

As margens, num raio de 100m (de acordo com a legislação), são consideradas área de preservação permanente (APP).

4. Saber se existe alguma legislação específica aplicada ao lago:

Não tenho conhecimento de legislação exclusiva para o lago, mas pode ser consultada a página da agência ambiental do GO, que disponibiliza legislação ambiental para os recursos hídricos dentro de GO.

5. Eu gostaria de saber da atuação do IBAMA: Há existência ou não de operações de fiscalização executadas atualmente pelo IBAMA no lago de Serra da Mesa?

Sim, o IBAMA constantemente realiza operações de fiscalização no lago. Para o ano de 2011, de acordo com o PNAPA (Planejamento Anual), há operações de fiscalização para serem executadas no lago de Serra da Mesa, especialmente com relação à pesca predatória.

6. A quem compete a função fiscalizatória?

Institucionalmente, compete à União (IBAMA), estado (SEMARH e Polícia Ambiental) e municípios (secretarias municipais de Meio Ambiente). No âmbito do IBAMA, a fiscalização se dá por meio dos seus servidores, em especial, os agentes ambientais federais (fiscais nomeados por portaria do presidente do IBAMA para realizar a fiscalização ambiental). Muitas vezes, as ações são feitas em parceria com os órgãos. Mas é sempre bom colocar que a preservação do lago depende de todos, não só dos órgãos fiscalizadores.

\section{Como são executadas essas operações?}

Em geral, são realizadas por meio aquático e terrestre, com servidores de diferentes localidades do IBAMA de Goiás e participação de agentes de outras instituições. 


\section{Com que freqüência?}

Em especial para este ano, o IBAMA organizou o PNAPA, seu planejamento de ações fiscalizatórias para 2011. Nele há operações para o lago, mas não se pode dizer com que freqüência serão realizadas, em alguns casos, por questões estratégicas de ação no combate às infrações ambientais.

9. Existem Medidas preventivas e/ou educativas aplicadas pelo órgão?

As principais medidas seriam a realização de atividades voltadas para a educação ambiental, liderada pelo Núcleo de Educação Ambiental (NEA) na superintendência; exposições e atividades de conscientização em eventos; e prestação de informações por meio da Linha Verde (fone: 080061 8080) e diretamente no Escritório Regional de Uruaçu.

10. E Medidas para reparar os danos causados?

A reparação dos danos, quando cabível, é uma exigência obrigatória e incluída dentro do processo que é aberto quando de uma autuação. Pode ser definida pela autoridade julgadora ou, quando crime ambiental, por um juiz.

11. Existe fiscalização em relação à exploração turística do lago? Por exemplo, em Uruaçu GO há uma praia artificial na beira do Lago, com vários restaurantes e bares feitos em grandes flutuantes, que provavelmente devem poluir o lago com algum tipo de detrito.

Cabem algumas considerações iniciais. Primeiro, cabe avaliar se estes flutuantes estão em área de APP, que é uma área de especial preservação. No entanto, a sua alteração e aproveitamento pode ser liberado quando é para uso público (ex.: praias, portos, etc.). Segundo, cabe sim o licenciamento ambiental, mas este é realizado pelo órgão estadual de meio ambiente. Terceiro, deve ter sido elaborado um plano de uso da área das margens do lago pela empresa que faz uso da UHE (no caso, Furnas), quando do licenciamento da UHE. Quarto, deve-se destacar que nem todo aporte de resíduos e líquidos em um corpo d’água podem ser considerados poluição. Existem limites estipulados por lei e que devem ser respeitados, e a caracterização de poluição deve ser feita mediante análise laboratorial (ver abaixo trecho do Decreto 6.514/08):

Das Infrações Relativas à Poluição e outras Infrações Ambientais 
Art. 61. Causar poluição de qualquer natureza em níveis tais que resultem ou possam resultar em danos à saúde humana, ou que provoquem a mortandade de animais ou a destruição significativa da biodiversidade:

Multa de $\mathrm{R} \$ 5.000,00$ (cinco mil reais) a $\mathrm{R} \$ 50.000 .000,00$ (cinqüenta milhões de reais).

Parágrafo único. As multas e demais penalidades de que trata o caput serão aplicadas após laudo técnico elaborado pelo órgão ambiental competente, identificando a dimensão do dano decorrente da infração e em conformidade com a gradação do impacto.

12. E em relação à pesca?

Muitas operações já foram realizadas no lago, no que se refere à pesca em anos anteriores, e há operações previstas para este ano de 2011. No dia 04/02/2011 foi assinado um convenio de cooperação entre IBAMA-GO e Associação de Ecologia e Pesca Esportiva (ANEPE) para o apoio em ações de fiscalização, atividades educativas e pesquisa científica com o tucunaré, afim de subsidiar legislações futuras.

13. E em relação à ocupação para moradia na área que margeia o Lago?

Não tenho informações a respeito. Somente soube informalmente que FURNAS vem notificando todos os proprietários que possuem construções em área irregular às margens do lago, para que estas sejam retiradas. 


\section{APÊNDICE D - Pesquisa de Campo - $2^{\text {a }}$ Etapa}

\section{Roteiro da entrevista realizada com uma Analista Ambiental do Núcleo de Licenciamento Ambiental do IBAMA/Goiânia - GO.}

Estou realizando uma pesquisa onde pretendo constatar a poluição das águas do Lago Serra da Mesa, suas causas e conseqüências, e a atuação do IBAMA em relação a essa poluição. Este estudo servirá de base para elaboração da minha Monografia.

A poluição do Lago Serra da Mesa pode ser observada em diversos pontos do reservatório; lixo, garrafas pet, redes de pescadores, etc. Além dessa poluição visível a olho nu, em pesquisa bibliográfica tomei conhecimento da contaminação da água (por vários agentes causadores, como contaminação por algas tóxicas, mercúrio, alumínio, etc.) segundo relatórios de Laboratórios de Análises Ambientais.

1. Primeiramente preciso de dados que comprove essa poluição; O que eu gostaria de saber do IBAMA é se existe algum documento (relatório) nesse sentido que eu possa ter acesso?

Sim, um documento que é público e qualquer um pode ter acesso é o Relatório Final 2005/2007 do Programa de Monitoramento Limnológico e da Qualidade da água do reservatório da UHE - Serra da Mesa. Este documento apresenta uma avaliação limnológica e da qualidade da água para o período de monitoramento do sistema hídrico do reservatório da UHE - Serra da Mesa. Você poderá tirar uma cópia.

2. Saber a respeito do Licenciamento Ambiental para funcionamento da UHE SERRA DA MESA; Para a concessão da licença foram realizados os estudos de impacto ambiental para instalação da UHE?

A licença de funcionamento da UHE Serra da Mesa foi concedida a época, pela Agencia Ambiental do Estado de Goiás, sem concretizar todos os estudos de impacto ambiental, só passando para responsabilidade do IBAMA no ano de 2005. Após uma Ação Civil Pública iniciada na época pela Associação dos Pescadores, APEGO, pedindo uma avaliação dos impactos ambientais. Inicialmente o processo foi para Brasília, passando depois para Goiânia, para o Núcleo de Licenciamento Ambiental, já com a licença vencida. Hoje o 
IBAMA trabalha no processo de renovação dessas LO. Foi exigida da empresa empreendedora uma série de estudos que estão sendo analisados. Conforme boletim técnico do Programa de Monitoramento Limnológico e da Qualidade da Água do Reservatório da UHE de Serra da Mesa, disponível para consulta ao público interessado.

3. Após a instalação da UHE foram realizados novos estudos de impacto ambiental? A quem competem esses estudos?

Os estudos de impacto ambiental não é competência do IBAMA, após a transferência do licenciamento ambiental da UHE Serra da Mesa para o IBAMA foi determinado que o IBAMA estabelecesse objetivamente às providências de reparação e de mitigação dos danos ambientais decorrentes da instalação da usina, cobrando da empresa empreendedora as medidas cabíveis. Então é isso, o IBAMA estabelece medidas a serem implementadas e analisa se as medidas estão seguindo os parâmetros e prazos determinados. Recentemente o IBAMA emitiu parecer técnico a respeito de documentos que contêm uma série de medidas que deverão ser implementada por Furnas, empreendedora da UHE Serra da Mesa. O qual poderá ser consultado.

4. Existem estudos por parte do IBAMA sobre a poluição do lago? Se existe o que foi descoberto com esses estudos?

Não, neste caso quem realiza os estudos são empresas contratadas pelos empreendedores, como no caso da UHE Serra da Mesa, a SEMESA S.A. contratou a MULTIGEO Mineração, Geologia e Meio Ambiente Ltda., que dará continuidade ao programa desenvolvido desde 1996, com a supervisão de técnicos do Departamento de Meio Ambiente de FURNAS. A parte nossa é solicitar os estudos e analisar os estudos realizados. Recentemente o IBAMA pediu um estudo sobre os níveis de mercúrio na água, eles já estão fazendo um levantamento do nível de mercúrio no pescado, agora será feito um monitoramento do mercúrio na água e nos sedimentos.

5. Saber se existe alguma legislação específica aplicada ao lago:

Não tenho conhecimento. Da parte do IBAMA não.

6. Gostaria de saber se o IBAMA realizou algum estudo da qualidade do meio ambiente da região de Uruaçu desde o início da operação da UHE Serra da Mesa. Caso afirmativo, posso ter acesso ao documento? 
O IBAMA não realiza esses estudos, ele determina que seja feito e analisa. Conforme parecer técnico emitido pelo IBAMA em 14 de dezembro de 2010, poderá ser observada análise de algumas medidas efetuadas por FURNAS, em atendimento a solicitação do IBAMA, relacionadas ao estudo da qualidade do meio ambiente.

7. Em relação à degradação/poluição ambiental existem medidas preventivas e/ou educativas aplicadas pelo IBAMA na região de Uruaçu?

Aplicadas pelo IBAMA não tenho conhecimento. Mas em relação a medidas educativas existe o Plano de Comunicação Social e Educação Ambiental que faz parte das exigências que deverão ser implementadas por FURNAS. 


\section{APÊNDICE E - Pesquisa de Campo - $3^{\text {a }}$ Etapa}

\section{Roteiro da entrevista realizada com uma Técnica de Fiscalização do Departamento de Fiscalização do IBAMA/Goiânia - GO.}

Estou realizando uma pesquisa onde pretendo constatar a poluição das águas do Lago Serra da Mesa, suas causas e conseqüências, e a atuação do IBAMA em relação a essa poluição. Este estudo servirá de base para elaboração da minha Monografia.

1. Parte do meu estudo está direcionada à região de Uruaçu - GO; Eu gostaria de saber da atuação do IBAMA na região de Uruaçu, a quem compete a função fiscalizatória na região de Uruaçu?

As operações de fiscalização quando já programadas pelo planejamento são realizadas por equipes que saem dos Estados para os municípios e recebem apoio dos órgãos regionais do IBAMA e de outros órgãos se for necessário.

2. Existem operações de fiscalização executadas atualmente pelo IBAMA no lago de Serra da Mesa, na região de Uruaçu - GO? Se existe como são executadas essas operações, e com que freqüência?

Essa semana foi uma equipe para Uruaçu, Niquelândia, Minaçu, e região, basicamente para trabalhar com pesca predatória, que é a prioridade desta operação, em razão da Piracema, período de reprodução das espécies, que iniciou em 1 de novembro e vai até 28 de fevereiro deste ano. Mas, pode ocorrer a fiscalização em outras áreas, como desmatamento, por exemplo, vai depender da demanda, ou se houver denúncias. A fiscalização do IBAMA basicamente trabalha da seguinte maneira, com planejamento que é feito um ano anterior, é realizada uma programação de todas as operações que vão acontecer, geralmente são operações que acontecem em nível nacional. Essa operação de pesca que está acontecendo agora aqui em Goiás, está acontecendo em outros estados do Brasil ao mesmo tempo. Por que isso foi definido em dezembro do ano passado, faz-se uma reunião nacional onde cada estado vai apresentar sua programação, que será aprovada ou não pela diretoria. Então durante o ano a gente já sabe previamente os locais e as operações que vão ser feitas. No caso de operação de pesca são operações realizadas normalmente em épocas que existe uma pressão maior 
sobre determinado rio ou reservatório, como feriados e férias, por exemplo, ou em caso de defeso (piracema). No reservatório o problema maior é em relação a pesca com fins comerciais, ou seja, predatória. Para auxiliar nesse trabalho de fiscalização o IBAMA também trabalha com parcerias como da Polícia Federal e Polícia Rodoviária Federal, como é o caso de fiscalização em rodovias, temos também apoio da SEMARH.

3. E em relação à pesca, existem dados de controle e ou de fiscalização? Já houve a aplicação de penalidades administrativas ambientais naquela região? (Uruaçu). Caso afirmativo, podemse precisar quantitativamente essas penalidades?

Hoje eu não teria em mãos esses dados, nem temos esses dados divulgados por nenhum meio de comunicação. O que pode ser feito, e o acesso a essas informações é público, mas teria que ser feito um levantamento, e essa informação teria que ser gerada pela nossa chefia, através do sistema, ver quais autos foram lavrados na região de interesse. Neste caso os dados não seriam dados exclusivos de Uruaçu, não seria limitada a municípios e sim a região onde a equipe atuou.

4. E em relação à ocupação para moradia na área que margeia o lago, como é feita a fiscalização?

Se a ocupação estiver em Área de Preservação Permanente a pessoa vai ser autuada, embargada e notificada para retirar a moradia, muitas vezes essa retirada precisa ter uma avaliação técnica antes da demolição para uma avaliação dos danos. Nas áreas inundáveis é competência do empreendedor FURNAS, são áreas que já foram indenizadas por FURNAS, mas as pessoas ainda continuam lá, ou construíram mesmo sabendo que é área que poderá ser inundada. Em relação à ocupação, há algum tempo atrás foi iniciado um trabalho de fazer as autuações isoladamente, sem resultado satisfatório porque o problema é bem generalizado, são mais de três mil ocupações irregulares. Atualmente existe um trabalho conjunto, entre FURNAS, Ministério Público e IBAMA, está sendo feito um levantamento detalhado de todas as ocupações pra tentar fazer um acordo de desocupação, junto com os interessados, FURNAS e o Ministério Público. Não é um trabalho de fiscalização de rotina ou individual. Outro ponto é que essa questão da ocupação irregular é bem complicada porque envolve embargo e demolição. Não é só ir lá e aplicar uma multa, existe a questão do dano, havendo a demolição é necessária a recuperação da área, há a necessidade de uma avaliação técnica, não é uma questão que será resolvida administrativamente. Normalmente vai pra justiça, leva tempo. O objetivo da fiscalização não é a multa e sim evitar que o dano aconteça, se acontecer 
a multa é por que já aconteceu o dano, pra reverter isso vai ser preciso fazer a demolição e a recuperação da área, é um processo oneroso pra pessoa que geralmente recorre a justiça e a desocupação em si demora a acontecer efetivamente.

5. Como funciona o processo de fiscalização através de denúncias?

O IBAMA tem um canal onde podem ser feitas denúncias pelo $n^{\circ} 080061$ 8080, é de nível nacional, uma central em Brasília recebe as denúncias e encaminha aos Estados. Onde é feita uma triagem podendo ser encaminhadas aos municípios, dependendo do tipo de denúncia ou do local. O IBAMA não atende a todas as denúncias, por que é competência comum dos estados e municípios com suas secretarias com seu aparato de também fazer esse trabalho. Por exemplo, aqui em Goiânia a AMMA - Agência Municipal do Meio Ambiente tem o Telefone verde, 161, funcionando 24 horas por dia, sete dias na semana, além de dar informações também recebe denúncias. Em Uruaçu tem a Secretaria de Meio Ambiente que também recebe; a SEMAH também recebe, enfim, todos têm competência para atender as denúncias. 
ANEXO A - Organograma do Instituto Brasileiro do Meio Ambiente e dos Recursos Naturais Renováveis - IBAMA

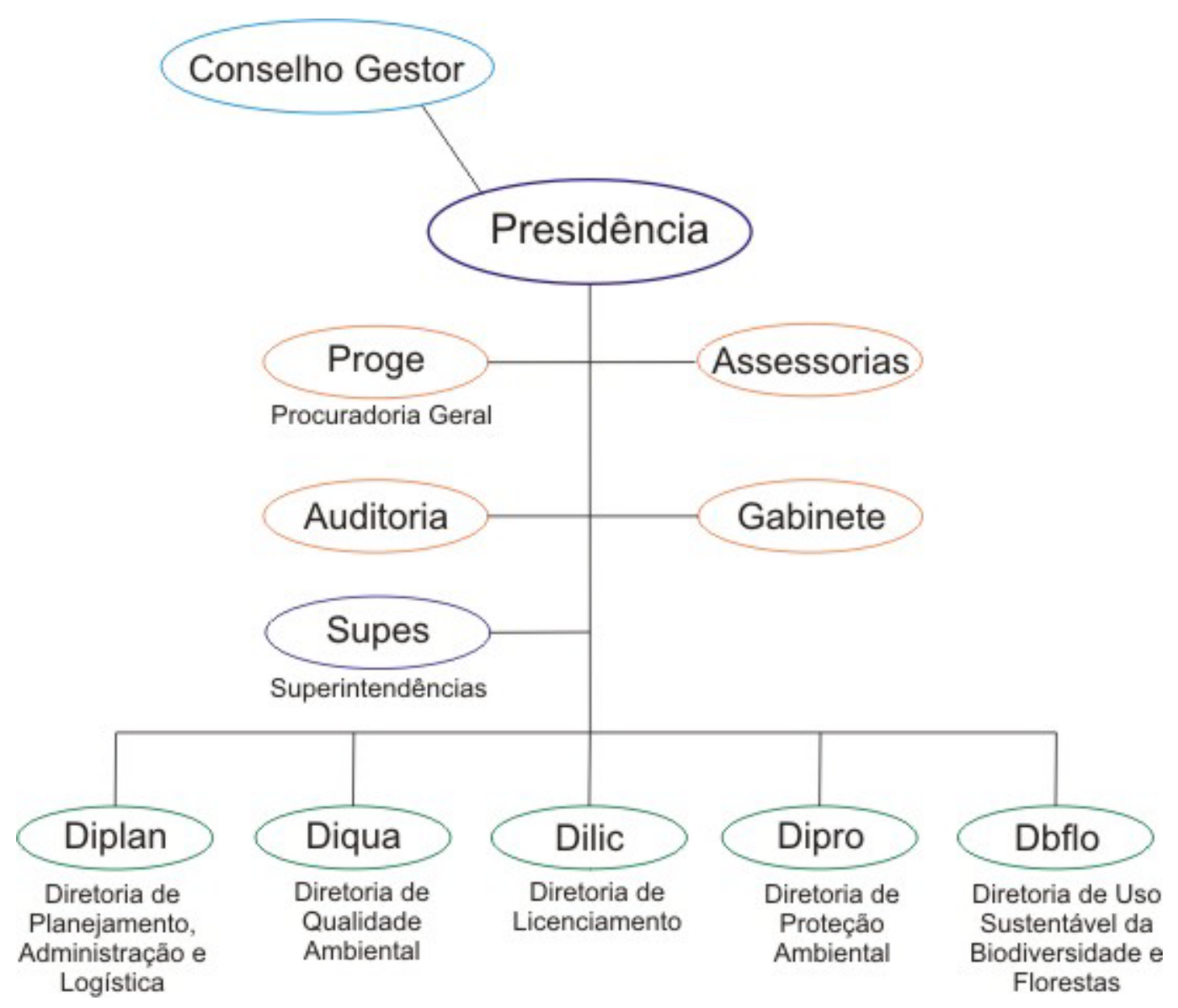

Fonte: Sitio do IBAMA - Instituto Brasileiro do Meio Ambiente e dos Recursos Naturais Renováveis 


\section{ANEXO B - Nota Técnica nº 10/2010-COLIC/DGPA/IBAMA-GO}

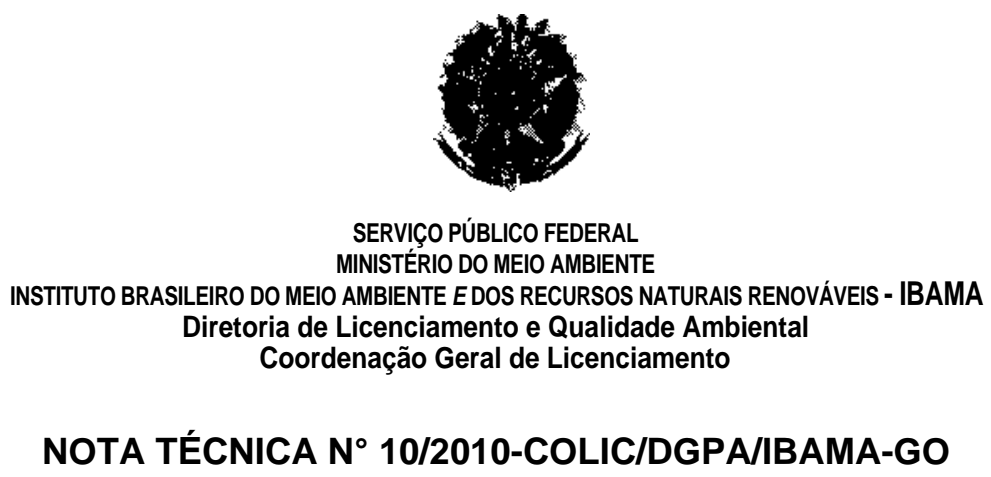

Goiânia, 15 de setembro de 2010.

Dos Técnicos: Ana Carolina Bonifácio da Silva

Dilermando Honório Eduardo

da Costa de Assis Luciana

Miyahara Teixeira Ruimar

Bernardo da Silva

Ao: Chefe da DGPA/GO

José Augusto de Oliveira Motta

Assunto: Processo 02010.004106/2004-21 - UHE Serra da Mesa

\section{I - INTRODUÇÃO}

A presente Nota Técnica tem por objetivo atender ao Despacho $n^{\circ}$ 2762/2010 (Processo 02010.004106/2004-21) referente ao Processo Judicial $n^{\circ}$ 2004.35.00.018667-7, o qual trata de Ação Civil Pública ajuizada pela Associação dos Pescadores Esportivos do Estado de Goiás (APEGO) em desfavor da AGAMA, IBAMA, FURNAS e SEMESA S.A.

Após transferência do licenciamento ambiental da UHE Serra da Mesa para o IBAMA, foi determinado que o IBAMA estabelecesse objetivameníe as providências de reparação e de mitigação dos danos ambientais decorrentes da instalação da usina, com prazo de 90 (noventa) dias contados a partir de 22/07/2010, improrrogáveis.

\section{II - DA ANÁLISE DO PROCESSO}

Após análise da documentação constante dos Processos IBAMA 02010.004106/2004-21 e 02001.005463/2005-04 e da Ação Civil Pública em questão, a equipe averiguou que face da situação atual do empreendimento e considerando a determinação do Operador Nacional do Sistema (ONS) para que a UHE Serra da Mesa opere na sua cota máxima de 460m, a qual não 
foi atingida desde a entrada em operação da UHE, há necessidade de estabelecer à Eletrobras Furnas uma série de medidas a serem implementadas. Tais medidas vão da retomada de ações de monitoramento e de programas ao estabelecimento do planejamento para desmobilização de edificações construídas por terceiros nas áreas pertencentes à Furnas e desmate das áreas a serem inundadas.

O estabelecimento de tais medidas servirá como diretriz para a renovação da Licença de Operação da UHE Serra da Mesa.

\section{III - DAS MEDIDAS}

\section{No prazo de 45 dias:}

- Apresentar Plano de Desmatamento dos Remanescentes de Vegetação, tendo em vista a retomada do enchimento do reservatório;

- Apresentar Plano de Resgate de Fauna para o desmatamento, seguindo a Instrução Normativa IBAMA n 146/2007;

- Apresentar Plano de Resgate de Fauna, em função da retomada do enchimento do reservatório, para fauna ilhada. O plano deverá contemplar o preconizado na Instrução Normativa IBAMA n 146/2007;

- Informar se novas cavidades naturais serão inundadas com a elevação da cota do reservatório. Caso ocorra inundação de novas cavidades naturais, apresentar Plano de Monitoramento e Combate a Raiva Animal;

- Apresentar Plano de Comunicação Social em vista da retomada do enchimento do reservatório. O plano deverá contemplar veículos de comunicação de massa regionais (rádios) e jornais de grande circulação;

- Apresentar levantamento das construções e edificações que se encontram dentro da área de inundação na área pertencente à Furnas;

- Apresentar plano de desmobilização das construções irregulares na área de Furnas;

- Apresentar plano para demarcação da cota máxima de inundação, priorizando as áreas onde há loteamentos irregulares;

- Apresentar Programa de Educação Ambiental com objetivo de orientar a população sobre a fuga de animais devido ao enchimento do reservatório. Este programa deverá 
apresentar à população da Área Diretamente Afetada os procedimentos a serem adotados quanto a possível invasão das propriedades por tais animais, informando telefones das equipes responsáveis pelo resgate de fauna e sanções previstas em lei quanto a caça de animais silvestres e pesca predatória;

- Apresentar proposta de orientação para a população sobre a presença de mercúrio no plâncton, sedimento, água e pescado do reservatório da UHE Serra da Mesa;

- Apresentar proposta para o Plano de Monitoramento de Mercúrio no reservatório, contemplando:

1. Campanhas semestrais, abrangendo o período de chuvas e seca da região;

2. Deverão ser monitorados plâncton (fito e zooplâncton), material em suspensão, sedimento e ictiofauna;

3. A metodologia de coleta de ictiofauna deverá contemplar todas as guildas tróficas e faixas de desenvolvimento dos peixes (principalmente adulta), além das principais espécies de pescado consumidas, permitindo a análise da biomagnificação do mercúrio;

4. No âmbito dos métodos analíticos, apresentar os limites de detecção para os diferentes compartimentos estudados (plâncton, água, sedimento e peixe);

5. Detalhar procedimentos metodológicos e apresentar dados básicos das campanhas como localizações espaciais das estações amostrais com coordenadas geográficas e mapa, dia e hora das amostragens, profundidade de coleta das amostras na coluna d'água, temperatura do ar;

6. Os locais de coleta deverão contemplar pontos a montante, no corpo do reservatório, próximos à barragem e a jusante da mesma;

7. Especificar os métodos analíticos para cada grupo estudado.

- Apresentar proposta para avaliação da estimativa de consumo de pescado pela população da Área Diretamente Afetada pelo reservatório.

\section{No prazo de 90 dias:}

- Apresentar Inventário Florestal das áreas onde será realizada a supressão da vegetação na área de inundação; 
- Apresentar Plano de Monitoramento do lençol freático da Área de Influência Direta do reservatório;

- Apresentar Plano de Monitoramento do $\mathrm{CO}_{2}$ e $\mathrm{CH}_{4}$ produzidos pelo reservatório, do momento atual até três anos após elevação à cota máxima;

- Apresentar o Plano de Monitoramento de Fauna conforme previsto na IN n 146/2007, contemplando o início do resgate de fauna até um ano após o prazo previsto para elevação do reservatório até a cota máxima. Este Plano deverá abranger ainda: caracterização dos ecossistemas nas áreas de influência do empreendimento avaliando os biótopos, ecótonos, ilhas de biodiversidade, trampolins, corredores ecológicos e outras formas de conexões biológicas existentes na área de influência, indicando as fitofisionomias e a florística, com vistas à identificação de áreas que possam ser utilizadas para 0 suporte e manejo da fauna e flora;

- Identificar os pontos de erosão e assoreamento existentes, com objetivo de estabelecer o seu nível de criticidade e a determinação daquelas que são prioritárias para correção;

- Elaborar PRAD visando a estabilização dos processos erosivos e de assoreamento com indicação de obras complementares e priorização de setores para estabilização;

- Identificar e mapear as áreas degradadas decorrentes da implantação e operação do empreendimento, avaliando o seu estado de recuperação (jazidas, canteiros de obras, áreas de empréstimo, bota-fora, etc.);

- Elaborar PRAD para recuperação das áreas degradadas decorrentes da implantação e operação do empreendimento;

- Identificar e georreferenciar em mapa as Áreas de Preservação Permanente, Unidades de Conservação, Áreas Prioritárias para Conservação'e demais áreas protegidas pela legislação;

- Justificar a permanência de vegetação inundada em deterioração no fundo do reservatório da UHE Serra da Mesa, bem como a necessidade ou impossibilidade de retirada parcial;

- Apresentar levantamento das Reservas Legais das propriedades parcialmente antingidas pelo enchimento do reservatório que foram relocadas. Para melhor visualização apresentar as informações em forma de mapa. 


\section{Dar continuidade, apresentando relatórios semestrais:}

- Ao Monitoramento sismológico da região para verificação de sismicidade induzida e sua intensidade;

- Ao monitoramento e ações de prevenção de doenças como malária, esquistossomose, raiva animal, febre amarela silvestre, leishmaniose e dengue;

- Ao Monitoramento Limnológico;

- Ao Monitoramento de Ictiofauna.

\section{No prazo de 365 dias;}

- Realizar levantamento batimétrico do reservatório, considerando o aporte de sedimento pêlos principais tributários. Apresentar relatório consolidado ao final desse prazo, a fim de avaliar a necessidade da continuidade e peridiocidade do mesmo.

\section{Dar continuidade, apresentando relatórios anuais:}

- Monitoramento climatológico, tendo em vista a elevação do reservatório até sua cota máxima. O monitoramento deverá ser realizado pelo período de três anos após o reservatório atingir sua cota máxima.

\section{Recomendacões Gerais}

- Para permitir a análise integrada dos diversos grupos faunísticos e florísticos, as unidades amostrais devem ser caracterizadas e georreferenciadas, identificando-as segundo os diferentes grupos amostrados;

- Detalhar a metodologia, o esforço e a intensidade amostrai por unidade e período, apresentando a localização e a sazonalidade das campanhas dos estudos atuais e anteriores, se utilizados;

- Em todos os Programas de Monitoramento, padronizar e manter a metodologia de coleta e análise das amostras, mesmo quando houver mudança de laboratório.

- Os dados limnológicos deverão:

1. Estabelecer rotina de monitoramento mantendo a frequência pré-estabelecida das campanhas, bem como a manutenção das localidades amostradas; 
2. Apresentar lista das espécies de cianobactérias detectadas, com as respectivas densidades, abundância relativa, riqueza e diversidade;

3. Padronizar metodologia de coleta e análise;

4. Monitorar cianotoxinas quanto a densidade de cianobactérias for superior a $20.000 \mathrm{cel} / \mathrm{mL}$ nos pontos de captação e abastecimento de água para abastecimento doméstico e, $50.000 \mathrm{cel} / \mathrm{mL}$ nas áreas de recreação e dessedentação de animais;

5. Prever ações de controle, caso seja identificada ocorrência e proliferação de cianobactérias potencialmente tóxicas, dentre outros aspectos considerados relevantes;

6. Manter o procedimento de contagem de fitoplâncton ao longo do monitoramento e explicitar o método usado para produzir análise integrada de quinze metros de profundidade;

7. Incorporar ao monitoramento de qualidade d'água a análise da concentração de fósforo existente nas camadas superiores da coluna d'água;

- Quanto aos estudos relativos à saúde pública, considerando os endemismos ocorrentes na região como malária, febre amarela, leishmaniose, recomenda-se que os estudos e as ações dos programas sejam realizados conforme o preconizado pelo Departamento de Vigilância em Saúde Ambiental e Saúde do Trabalhador, do Ministério da Saúde.

Esta é a nota técnica.

À consideração superior.

Ana Carolina Bonifácio da Silva

Analista Ambiental
Dilermando Honório

Analista Ambiental

\section{Eduardo da Costa de Assis}

Analista Ambiental

Luciana Miyahara Teixeira

Analista Ambiental
Ruimar Bernardo da Silva

Analista Ambiental 


\title{
ANEXO C - Parecer Técnico n 20/2010-COLIC/DGPA/IBAMA-GO
}

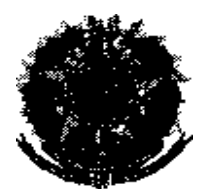 \\ SERVIÇOPÚBLICOFEDERAL \\ MINISIÉRIODOMEIOAMBIENIE \\ INSTIIUTOBRASIIEIRODOMEIOAMBENIEEDOSRECURSOSNATURAISRENOVÁVEIS-IBAMA \\ Diretoria de Licenciamento e Qualidade Ambiental \\ Coordenação Geral de Licenciamento
}

\section{PARECER TÉCNICO Nº 20/2010-COLIC/DGPA/IBAMA-GO}

Goiânia, 14 de dezembro de 2010.

Dos Técnicos: Ana Carolina Bonifácio da Silva - Analista Ambiental - Bióloga

Eduardo Costa de Assis - Analista Ambiental - Geógrafo

Dilermando Honório - Analista Ambiental - Engenheiro Agrónomo

Luciana Miyahara Teixeira - Analista Ambiental - Geóloga

Ruimar Bernardo da Silva - Analista Ambiental - Engenheiro Florestal

Ao: $\quad$ Fernando Augusto Di Franco Ribeiro

Chefe da DGPA

Assunto: Análise de documentação referente à UHE Serra da Mesa

Documentos: Plano de Comunicação Social e Educação Ambiental, Plano de Demarcação da Cota de Desapropriação do Reservatório, Plano de Monitoramento das Concentrações de Mercúrio em Diversos Compartimentos Biogeoquímicos do Reservatório, Levantamento das Cavidades Naturais. 


\section{1 - Introdução}

A UHE Serra da Mesa, localizada em Goiás, na Bacia do Alto Tocantins, entrou em operação em 1998 com três unidades geradoras (1.275MW) e está retomando o enchimento do reservatório até sua cota máxima de 460m. Localiza-se no trecho superior da bacia do rio Tocantins, com um volume acumulado de 54,4 bilhões de $\mathrm{m}^{3}$ de água numa área de $1.780 \mathrm{Km}^{2}$. Os municípios afetados pelo empreendimento são Barro Alto, Campinaçu, Campinorte, Colinas do Sul, Minaçu, Niquelândia, Santa Rita do Novo Destino e Uruaçu.

Neste parecer, serão analisados os seguintes documentos encaminhados pela Eletrobrás Furnas em atendimento ao Ofício/IBAMA-GO/DGPA $\mathrm{N}^{\circ}$ 758/2010: "Plano de Monitoramento das Concentrações de Mercúrio em Diversos Compartimentos Biogeoquímicos do Reservatório da UHE Serra da Mesa", "Plano de demarcação da Cota de Desapropriação do Reservatório da UHE Serra da Mesa", "Levantamento das Cavidades Naturais", "Plano de Comunicação Social e Educação Ambiental", "Identificação da Cobertura Vegetal Inundada pela. Retomada do Enchimento do Reservatório", "Levantamento das áreas protegidas no entorno do reservatório" e "Plano de Monitoramento do Lençol Freático".

\section{2 - Análise}

\subsection{Plano de Monitoramento das Concentraç̃es de Mercúrio em Diversos}

\section{Compartimentos Biogeoquímicos do Reservatório da UHE Serra da Mesa}

A contaminação dos ambientes aquáticos por mercúrio pode ocorrer naturalmente através de lixiviação/erosão de solos ricos nesse metal ou decorrente de ações antrópicas de mineração, especialmente garimpo de ouro, aporte industrial e doméstico ou através da deposição atmosférica. No ambiente aquático o mercúrio pode ser encontrado nas formas inorgânica e orgânica, sendo que as inorgânicas acumulam-se principalmente no sedimento, nos sólidos em suspensão e na coluna d'água. O mercúrio orgânico, na forma de metilmercúrio (MeHg, a forma mais tóxica de mercúrio), se encontra associado à biota aquática.

O mercúrio concentra-se na biota aquática até várias ordens de grandeza acima das concentrações encontradas na coluna d'água, sendo que a transferência é iniciada nos primeiros níveis tráficos da cadeia alimentar, representados por plâncton, passando pêlos peixes e chegando ao 
homem pelo consumo de pescado, sendo os maiores níveis de MeHg encontrados nos tecidos de organismos de topo de cadeia alimentar como os peixes predadores.

O plano de trabalho apresentado pelo empreendedor tem como objetivo trazer as ações necessárias para a análise das concentrações de mercúrio no ambiente (sedimentos e material particulado em suspensão) e nos organismos representantes de diversos níveis da cadeia alimentar local (fitoplâncton, zooplâncton, peixes detritívoros, herbívoros, onívoros, invertívoros e psicívoros) no reservatório da UHE Serra da Mesa.

Serão coletadas, semestralmente num período de cinco anos, amostras de sedimento, material em suspensão, fitoplâncton, zooplâncton e cinco guildas trófícas da ictiofauna. Serão utilizados, ainda, relatórios de Monitoramento Limnológico e Qualidade de Água da UHE Serra da Mesa (trimestral) para maior embasamento das análises.

Foram definidos 16 pontos de coleta dos quais seis se localizam no interior do reservatório, um a jusante da barragem de Serra da Mesa e nove nos principais tributários (rio das Almas, rio Passa Três, rio do Peixe, rio Traíras, rio Biliágua, rio Bagagem e Rio Tocantinzinho). Sugere-se que sejam coletadas amostras em mais dois pontos localizados na área do reservatório, nas proximidades das coordenadas $14^{\circ} 10^{\prime} \quad 28,38$ "S/48Ü48'24,82"S e $13^{\circ} 58^{\prime} 14,25^{\prime \prime S} / 48^{\circ} 20^{\prime} 51,28^{\prime \prime} \mathrm{W}$.

Serão amostradas: até 15 espécies de ictiofauna divididas nas cinco guildas propostas; fitoplâncton e zooplâncton em amostras integradas, referentes a cada comunidade por ponto de coleta; amostras de sedimento da região lótica e na zona de transição entre região lótica e lêntica; além de material em suspensão em todos os pontos de coleta.

Fitoplâncton e Zooplâncton: o fitoplâncton será coletado com dois arrastes horizontais e dois verticais (malha de 25 fim) e as amostras deverão ser transferidas para frascos de plástico refrigerados, sendo congeladas assim que possível e mantidas dessa maneira até o momento da liofilização. O zooplâncton será coletado com dois arrastes horizontais e dois verticais utilizando a rede de malha de 70 um, repetindo o procedimento com rede de 290 um. As amostras deverão ser transferidas para potes plásticos e congeladas até o momento de sua liofilização laboratorial. 


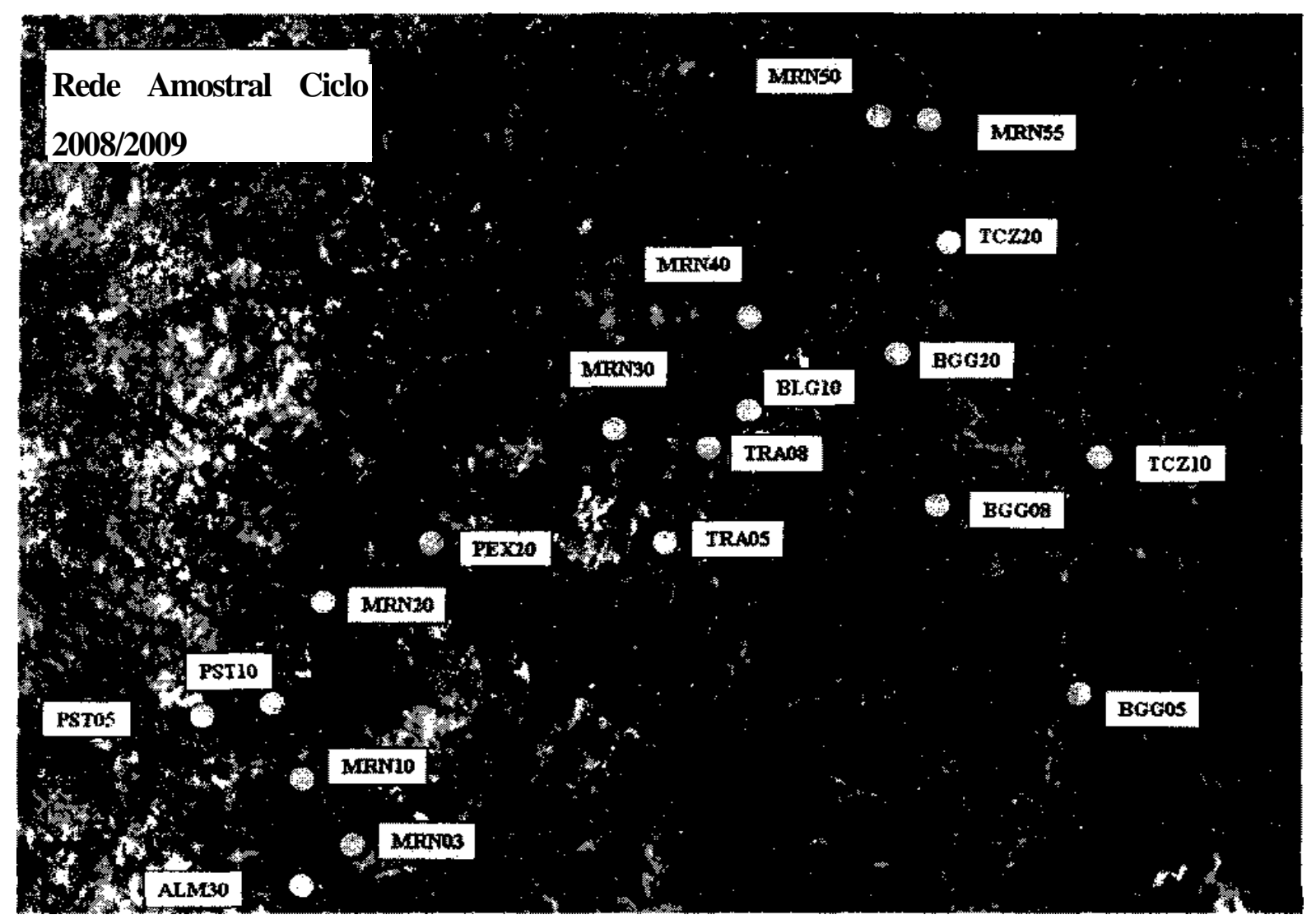

Ictiofauna: as amostras serão coletadas com redes de espera, de arrasto e tarrafas em oitos pontos (ALM-30, BGG-20, BLG-10, MRN-50, PST-10, PEX-10, TCZ-10.), dos quais dois representam o reservatório e os demais os tributários.

As espécies deverão ser selecionadas segundo a abundância nas coletas e hábitos alimentares. Os peixes serão lavados, pesados e medidos e terão seu tecido muscular dorsolateral removido (de acordo com recomendações da FAO), sendo congelados até o momento da análise para determinação das concentrações de Hg.

Materialparticulado: as amostras serão obtidas através da filtragem de amostras de água do reservatório. Serão coletados 4L (quatro litros) de água sub-superficial em cada um dos pontos de amostragem em garrafas plásticas descontaminadas com ácido nítrico e rinsadas com água do local. Serão utilizados filtros de fibra de vidro de 1 .2um Whatman GF/C previamente calcinados a $400^{\circ} \mathrm{C}$ por 24 horas e um sistema de filtração de vidro com bomba à vácuo. Os filtros serão congelados até o momento da determinação das concentrações de mercúrio.

Sedimento: os perfis verticais de sedimento serão coletados em tubos de acrílico enterrados verticalmente em regiões do reservatório permanentemente submersas fora da 
influência da erosão das margens onde ocorre material particulado em suspensão. Foram selecionados dez pontos, dois quais dois representam a na região lótica (MRN-03, MRN-10), sete os principais tributários (ALM-30, PST-10, PEX-10, TRA-08, BLG-10, BGG-05, TCZ-10) e um na zona de transição entre a região lótica e lêntica (MRN-20). De modo geral, os sedimentos serão coletados próximos às bordas do reservatório, em pontos com pequena profundidade. Embora se saiba que o lago de Serra da Mesa é profundo, com regiões onde a profundidade pode atingir os 100 metros, sugere-se que seja analisada a possibilidade de se coletar amostras de sedimento na região dos pontos BGG08 e MRN30.

Os sedimentos deverão ser cortados em fatias com três centímetros de espessura e acondicionados em sacos plásticos individuais e congelados. As amostras deverão ser secas em estufa a $60^{\circ} \mathrm{C}$, separadas em duas frações granulométricas uma com grãos maiores e outra com grãos menores de 70um, sendo que apenas a fração mais fina será usada para determinação das concentrações de mercúrio.

Metodologia de análise laboratorial: as amostras de peixes e sedimento passarão por digestão ácida a quente em sistema aberto com utilização de tubos de ensaio e banho-maria. Já as amostras de plâncíon e material particulado em suspensão passarão por digestão ácida a quente em sistema fechado (forno de microondas). As concentrações de mercúrio nas amostras serão determinadas por fluxo de injeção com utilização do borohidreto de sódio como agente redutor. Deverá ser respeitado o limite mínimo de detecção de 0,05 ppb.

Produtos: serão elaborados relatórios semestrais contendo os laudos das análises químicas e estatística básica dos dados. Deverão ser, ainda, apresentadas as coordenadas geográficas das estações amostrais, mapa com posicionamento e registro fotográfico das estações amostrais, dia, hora e condições climáticas das amostragens, profundidade da coluna d'água, temperatura da água e do ar. Serão ainda propostas medidas mitigadoras e de controle do pescado caso seja observado um cenário crítico. Será gerado ainda, um relatório conclusivo com os resultados de todas as análises a fim de gerar um panorama das concentrações de mercúrio em cada compartimento biogeoquímico do reservatório.

Materialparticulado: as amostras serão obtidas através da filtragem de amostras de água do reservatório. Serão coíetados 4L (quatro litros) de água sub-superficial em cada um dos pontos de amostragem em garrafas plásticas descontaminadas com ácido nítrico e rinsadas com água do local. Serão utilizados filtros de fibra de vidro de $1.2 \mid$ um Whatman GF/C previamente calcinados a $400^{\circ} \mathrm{C}$ por 24 horas e um sistema de filtração de vidro com bomba à vácuo. Os filtros serão congelados até o momento da determinação das concentrações de mercúrio.

Sedimento: os perfis verticais de sedimento serão coíetados em tubos de acrílico enterrados verticalmente em regiões do reservatório permanentemente submersas fora da influência da erosão das margens onde ocorre material particulado em suspensão. Foram 
selecionados dez pontos, dois quais dois representam a na região lótica (MRN-03, MRN-10), sete os principais tributários (ALM-30, PST-10, PEX-10, TRA-08, BLG-10, BGG-05, TCZ-10) e um na zona de transição entre a região lótica e lêntica (MRN-20). De modo geral, os sedimentos serão coíetados próximos às bordas do reservatório, em pontos com pequena profundidade. Embora se saiba que o lago de Serra da Mesa é profundo, com regiões onde a profundidade pode atingir os 100 metros, sugere-se que seja analisada a possibilidade de se coletar amostras de sedimento na região dos pontos BGG08 e MRN30.

Os sedimentos deverão ser cortados em fatias com três centímetros de espessura e acondicionados em sacos plásticos individuais e congelados. As amostras deverão ser secas em estufa a $60^{\circ} \mathrm{C}$, separadas em duas frações granulométricas uma com grãos maiores e outra com grãos menores de 70um, sendo que apenas a fração mais fina será usada para determinação das concentrações de mercúrio.

Metodologia de análise laboratorial: as amostras de peixes e sedimento passarão por digestão ácida a quente em sistema aberto com utilização de tubos de ensaio e banho-maria. Já as amostras de plâncton e material particulado em suspensão passarão por digestão ácida a quente em sistema fechado (forno de microondas). As concentrações de mercúrio nas amostras serão determinadas por fluxo de injeção com utilização do borohidreto de sódio como agente redutor. Deverá ser respeitado o limite mínimo de detecção de 0,05 ppb.

Produtos: serão elaborados relatórios semestrais contendo os laudos das análises químicas e estatística básica dos dados. Deverão ser, ainda, apresentadas as coordenadas geográficas das estações amostrais, mapa com posicionamento e registro fotográfico das estações amostrais, dia, hora e condições climáticas das amostragens, profundidade da coluna d'água, temperatura da água e do ar. Serão ainda propostas medidas mitigadoras e de controle do pescado caso seja observado um cenário crítico. Será gerado ainda, um relatório conclusivo com os resultados de todas as análises a fim de gerar um panorama das concentrações de mercúrio em cada compartimento biogeoquímico do reservatório. Detalhar a amostragem de ictiofauna para obtenção da licença de monitoramento.

\subsection{Plano de demarcação da cota de desapropriação do reservatório da UHE Serra da}

\section{$\underline{\text { Mesa }}$}

O plano apresentado tem por objetivo estabelecer procedimentos para a demarcação da cota de desapropriação da UHE Serra da Mesa visando a preservação da área patrimonial da empresa. Serão demarcados os limites da área de concessão do entorno do reservatório para conhecimento dos interessados e para impedir o uso e ocupação irregular. 
Estão previstas a comunicação aos proprietários lindeiros sobre a existência do projeto de demarcação além de um serviço de fiscalização dos marcos a cargo de FURNAS para garantir a integridade dos mesmos, providenciando sua substituição quando necessário.

A demarcação das áreas foi determinada a partir da análise das ortofotocartas do entorno do reservatório por um grupo de especialistas em SIG, engenheiros e topógrafos. Será concentrada em regiões de grande pressão imobiliárias e de interesse estratégico para FURNAS e de fácil acesso pela população, sendo instalados em intervalos que possam servir de referência para os proprietários confrontantes com o reservatório. Não serão demarcadas áreas de difícil acesso e/ou topografia acidentada (escarpas, grotas, brejos, matas fechadas). Cada marco será numerado e georrefenciado.

Serão utilizados três tipos de marcos: perfil de aço galvanizado, concreto e trilho. Todos os marcos serão pintados com tinta amarela e com indicação do lveb site de FURNAS e de um telefone de contato. Preferencialmente, serão instalados marcos com perfil de aço galvanizado. Após o esgotamento dos estoques deste, se utilizarão os marcos de concreto armado e, só em caso de vandalismo continuado, será instalado o marco de trilho. Para dimensionamento do espaçamento entre os marcos será considerada a topografia do terreno, observando a visualização entre eles, orientando os proprietários confrontantes e facilitando a fiscalização. Os marcos serão plotados em uma planta, que será disponibilizada aos interessados mediante solicitação.

A demarcação da cota de inundação será contínua, em observância a legislação vigente, estando prevista para três anos a execução total.

\subsection{Plano Geral de Desmatamento da UHE Serra da Mesa}

O plano de desmatamento apresentado traz o escopo do desmatamento proposto em 1996 por um grupo de trabalho composto por FURNAS, FEMAGO e IBAMA, intitulado "Planejamento da retirada prévia e aproveitamento de recursos florestais na área do reservatório".

Tal plano tinha como objetivo selecionar as áreas prioritárias para desmatamento considerando a qualidade da água, controle de vetores, aproveitamento económico da matéria-prima florestal, fauna terrestre e aquática e uso múltiplo do reservatório. Nesta época concluiu-se que a retirada da vegetação não alteraria as tendências gerais de eutrofização do reservatório formado. Foram definidas duas formas básicas de desmatamento: desmatamento prioritário e desmatamento recomendado, sendo assinado o Acordo de Cooperação n 11.477, em 19/04/1996, entre as partes envolvidas, com objetivo de sistematizar e dinamizar as ações que visavam a retirada prévia da madeira, com previsão de execução em trinta meses. 
Devido a dimensão do reservatório, na época foi realizada uma compartimentalização que resultou em seis segmentos:

- Segmento 01: 07\% da área de inundação, na margem esquerda do eixo da barragem, onde drenam o rio Boa Nova e os Córregos Carneiro e Lageado;

- Segmento 02: 47\% da área de inundação, entre a Serra Negra e Uruaçu;

- Segmento 03: 29\% da área de inundação, localizado no rio Bagagem, onde estão a Codemim e a Níquel Tocantis;

- Segmento 04: 06\% da área de inundação, no rio Tocantizinho, no braço mais encaixado no relevo montanhoso;

- Segmento 05: 02\% da área de inundação, no rio Traíras;

- Segmento 06: 09\% da área de inundação, no final do reservatório, próxima a cidade de Uruaçu.

Foi detectado, ainda, um uso de solo que resultava numa cobertura vegetal descontínua e heterogénea, sendo que o Campo Cerrado cobriria 65,68\% da área total do reservatório. Segundo FURNAS, o desmatamento seletivo na bacia de acumulação do reservatório teria efeito em alguns parâmetros de qualidade de água, mas que não alteraria substancialmente as tendências de evolução da eutrofização. Argumentaram que as alternativas de desmatamento que variam de 11.000 a 1OO.OOOha não refletiriam na qualidade da água, o que não justificaria investimento de grande monta para a limpeza do reservatório para melhoria da qualidade da água.

A Proposta Geral de Desmatamento indicava um Trecho Prioritário e um Trecho de Desmatamento Recomendado.

O Trecho Prioritário ficaria a cargo de FURNAS e compreenderia o desmatamento integral da Área I (imediatamente a montante da barragem) e o desmatamento dos demai ${ }^{1}$ trechos entre as cotas 440 e 460m. Este trecho seria diagnosticado como prioritário tendo en> vistas aspectos de segurança da usina, de controle sanitário, de possibilidade de instalação di infraestrutura de navegação regional, de recreação e lazer e aspectos paisagísticos. O Trecho de Desmatamento Recomendado seria aberto a interessados no aproveitamento económico da madeira compreendendo a faixa abaixo da cota $440 \mathrm{~m}$.

Com base nesse planejamento, FURNAS requereu em 1996 autorização de desmatamento global para toda a área da AHE Serra da Mesa, a qual foi concedida pelo IBAMA e pela FEMAGO sem data de validade.

Tendo em vista a retomada do enchimento do reservatório da UHE Serra da Mesa, segundo recomendação do ONS (Ordenador Nacional do Sistema), através da ALA.E.E.932.2010, de 
08/11/2010, FURNAS informa que foram identificados 2.992 fragmentos remanescentes de vegetação entre a cota atual e a cota 460, o que somaria 11.200ha. No entanto, a proposta de FURNAS é desmatar apenas o que foi previsto em 1996, correspondente a 180ha deste montante.

Considerando o crescente consumo de madeira para os diferentes usos (carvão, movelaria, construção civil, dentre outros) resultando no desmatamento de grandes áreas florestadas, cujo futuro aponta para um "apagão florestal", acredita-se que a não retirada da madeira inundável da área compreendida entre as cotas 440 e 460 da UHE Serra da Mesa, mesmo que sua permanência não traga grandes modificações na qualidade da água do reservatório, é do ponto de vista económico e ambiental uma grande perda de madeira aproveitável.

Deverá ser providenciado o desmatamento de modo a proporcionar o aproveitamento do material lenhoso que será submerso.

Propor o envio do plano de desmaie conforme a previsão de enchimento do reservatório, priorizando as áreas que serão submersas primeiro.

\subsection{Levantamento das Cavidades Naturais}

Para o levantamento das cavidades presentes na área do empreendimento, foram utilizadas várias fontes de dados, como estudos já realizados na região, tanto por FURNAS/IESA quanto pelo Instituto GEABRASIL, bem como a base de dados do Centro Nacional de Pesquisa e Conservação de Cavemas (CECAV).

Foram reconhecidas mais de 150 ocorrências de estruturas cársticas entre grutas, cavernas, dolinas e abismos, compreendendo áreas dos municípios de Colinas do Sul, Uruaçu, Niquelândia, Santa Rita do Novo Destino, Campinaçu e Minaçu, das quais 15 (quinze) foram consideradas de interesse, uma vez que se localizam dentro e nas proximidades da zona influenciada pelo enchimento completo do reservatório, podendo sofrer influência com a variação do N.A. local. Dessas quinze ocorrências, cinco estão localizadfas no unicípio de Santa Rita do Novo Destino, sete em Niquelândia, duas em Campinaçu e uma em Uruaçu (tabela abaixo).

Tabela 01: Cavidades naturais com possibilidade de serem inundadas com o enchimento completo do reservatório.

\begin{tabular}{|c|c|c|c|c|c|}
\hline Número & Nome da cavidade & Litologia & $\begin{array}{c}\text { Cota } \\
\text { Aproximada }\end{array}$ & $\begin{array}{c}\text { UTM } \\
(\mathrm{X})\end{array}$ & $\begin{array}{c}\text { UTM } \\
\text { (Y). }\end{array}$ \\
\hline 1 & Abismo Água Fria & Calcário & 460 & 800895 & 8412003 \\
\hline 2 & Abrigo do índio III & Calcário/ mica-xisto & 450 & 716402 & 8385977 \\
\hline 3 & Buraco das Vacas & Calcário & 470 & 742325 & 8431059 \\
\hline 4 & Caverna da Lapa & Calcário & 480 & 720192 & 8387913 \\
\hline
\end{tabular}




\begin{tabular}{|c|c|c|c|l|l|}
\hline 5 & Dolina do Alan & Calcário & 460 & 723567 & 8426474 \\
\hline 6 & Dolina Poço Encantado & Calcário & 460 & 715103 & 8381683 \\
\hline 7 & Gruta Caititu & Calcário & 450 & 786584 & 8458983 \\
\hline 8 & Gruta do Célio I & Calcário & 470 & 800348 & 8414070 \\
\hline 9 & Gruta do Célio II & Calcário & 470 & 800539 & 8414676 \\
\hline 10 & Gruta do índio I & Calcário /mica-xisto & 456 & 716254 & 8386288 \\
\hline 11 & Gruta do índio II & Calcário & 454 & 716275 & 8386322 \\
\hline 12 & Gruta do índio IV & Calcário & 450 & 716422 & 8386029 \\
\hline 13 & Gruta do Lago Azul & Calcário & 470 & 746423 & 8422010 \\
\hline 14 & Gruta Lagoas & Calcário & 460 & 798955 & 8413167 \\
\hline 15 & Gruta Taquarí & Calcário & 470 & 772640 & 8450367 \\
\hline
\end{tabular}

Com base no exposto acima, o relatório sugere que os dados coletados devem subsidiar um Plano de Monitoramento e Combate à Raiva Animal.

\subsection{Plano de Comunicação Social e Educacão Ambiental}

Este Plano visa atender as solicitações referentes às questões de comunicação social e educação ambiental constantes no OFÍCIO IBAMA-GO/DGPA N 758/2010.

O capitulo 1. Apresentação inicia-se com informações pertinentes à localização e abrangência do reservatório da Usina Hidrelétrica de Serra da Mesa. Em seguida, enfatiza que a entrada em operação da usina, foi de grande importância ao país, considerando a interligação dos Sistemas Sul/Sudeste/Centro-Oeste ao Sistema Norte-Nordeste, além de definir o abastecimento energético de Goiás e do Distrito Federal.

O plano informa ainda no capitulo 01, que os níveis do reservatório são variáveis em decorrência das necessidades do Sistema Nacional Elétrico. Essas variações geram uma necessidade de que haja ações de comunicação social e educação ambiental no entorno do reservatório.

Os temas propostos para a demanda em questão, a serem desenvolvidos pela equipe de campo incluem: segurança da população, risco de ocupações irregulares (áreas de agricultura, pecuária e construções diversas) nos terrenos de propriedade da Eletrobras Furnas, fornia de operação do reservatório, conservação das Áreas de Preservação Permanente, legislação ambiental, espécies em extinção, espécies peçonhentas, entre outros.

A execução deste plano está prevista para os municípios de Minaçu, Campinorte, Campinaçu, Colinas do Sul, Uruaçu, Niquelândia, Barro Alto e Santa Rita do Novo Destino.

O capítulo 2. Objetivo do Programa, afirma que o objetivo do geral do plano é criar meios e produtos que permitam a execução das atividades de comunicação social e educação ambiental previstas para a atual fase do empreendimento, que está em operação e com previsão de 
enchimento do reservatório, de forma a contribuir para a liberação de áreas de propriedade da Eletrobrás Furnas e de APP, bem como, a segurança da população viznha ao empreendimento.

O público - alvo do plano foi assim definido no capítulo 3:

- Ocupantes irregulares;

- População lindeira ao reservatório (área diretamente afetada);

- Associações representativas da população e líderes comunitários;

- Escolas, universidades, ONG's, centro de pesquisa, cursos técnicos e profissionalizantes.

O capítulo 4. Sistemática de trabalho foi dividido nos tópicos Planejamento e Implantação.

O tópico relativo ao planejamento prevê as ações de infraestrutura, que são:

- Identificar locais pertinentes à realização de eventuais reuniões informativas e as formas ideais de mobilização das comunidades (rádio, carros de som, cartazes, etc.);

- Identificar as escolas que estejam próximas à área a ser trabalhada, ou que recebam alinos provenientes dessas áreas;

- Disponibilizar um telefone celular para cada comunicador de campo. Os números dos telefones serão amplamente divulgados para atendimento da população.

Ainda referindo-se à fase de planejamento, o plano prevê a elaboração de materiais informativos para apoio às atividades desenvolvidas no campo, são eles:

- Folder específico sobre o empreendimento: apresentará informações sobre o empreendedor, as características técnicas da usina e a sobre a atual fase do empreendimento (incluindo a variação do nível do reservatório);- Cartazes: serão utilizados para divulgação das reuniões informativas e para informar sobre os cuidados a serem observados durante a variação de nível do reservatório;

- Fichas de demandas: material que reunirá todas as dúvidas, sugestões e reclamações geradas pela população;

- Cartilhas: material que deverá complementar as informações tratadas pela equipe de educação ambiental.

No item 4.2 o plano define a fase de sua implantação visando estabelecer um canal de comunicação entre a Eletrobrás Furnas e a comunidade.

Através de contatos individuais, o plano pretende garantir acesso a informações sobre o empreendimento, a empresa, bem como, quaisquer outras atividades relacionadas à UHE Serra da Mesa, distribuindo simultaneamente informativos da campanha.

A equipe responsável apresentará palestras em escolas e comunidades, sobre temas relativos à fase do empreendimento e/ou assuntos correlates, sempre que demandado. Haverá em 
específico um ciclo de palestras orientando a população dos municípios da Área de Influência do empreendimento, sobre a presença de mercúrio no plâncton, sedimento, água e pescado do reservatório da UHE Serra da Mesa, esta atividade está condicionada à conclusão dos estudos em andamento sobre a presença de mercúrio no reservatório.

Devido à especificidade do tema relativo ao mercúrio, pretende-se gerar um debate direcionado aos especialistas das áreas de saúde e meio ambiente de todos os municípios presentes na área de influência da UHE Serra da Mesa.

Para tratar da questão da fuga de animais, em virtude do enchimento do reservatório, os comunicadores apresentarão às comunidades presentes na Área Diretamente Afetada informações sobre segurança, sobre as sanções previstas em Lei quanto à caça e pesca predatória, bem como, informará os telefones das equipes responsáveis pelo resgate de fauna para eventuais consultas.

Para efetivar as propostas acima, pretende-se realizar as seguintes ações:

- Palestras para a população diretamente afetada;

- Slides dos animais elencados em 4.2.1, seus hábitos alimentares e reprodutivos;

Informação sobre como agir quanto à possível invasão das propriedades por animais;

- Apresentação da Lei de Crimes Ambientais e dramatização de situações/apresentações de casos;

- Palestras para o público em geral ministradas pêlos moradores locais.

Finalizando o plano prevê a elaboração de um plano de mídia que contemple informações sobre a renovação da Licença de Operação, bem como, a divulgação de ações e informações abordadas pelas equipes de campo.

O capítulo 5. Equipe Técnica, define que a equipe responsável pelo desenvolvimento do programa são:

- Dois profissionais com formação em Comunicação Social, para a função de comunicador social de campo, com sedes em Minaçu e Niquelândia;

- Dois especialistas em Educação Ambiental para desenvolverem pontualmente as atividades destinadas à comunidade escolar, universidades e lideranças comunitárias.

Considera-se que o Plano de Comunicação Social e Educação Ambiental atenderá as demandas que geraram a sua elaboração, de modo que tratará socialmente a questão da presença ou não do mercúrio no reservatório e seus elementos, assim como, a questão do enchimento do reservatório da UHE Serra da Mesa, no sentido mais amplo, incluindo questões relativas à fuga de animais e a caça predatória. 


\subsection{Levantamento das Áreas Protegidas no Entorno do Reservatório.}

O documento faz um levantamento das Unidades de Conservação existentes nas regiões próximas ao reservatório, incluindo Áreas de Proteção Ambiental, Áreas de Preservação Permanente, Reservas Indígenas, RPPNs e Parques Nacionais e Áreas Prioritárias para Conservação da Biodiversidade.

O levantamento foi feito a partir de dados secundários e levantamento de informações existentes em órgãos municipais, estaduais e federais, especialmente prefeituras, Sistema Estadual de Estatística e Informações Geográficas de Goiás e do Ministério do Meio Ambiente.

Foram identificadas as seguintes áreas protegidas:

Área de Preservação Permanente (APP) - foi informado que a APP do reservatório constitui uma faixa marginal com largura mínima de 100 metros a partir do nível máximo normal de operação do reservatório (460,00m). Em áreas urbanas consolidadas, a APP é de 30 metros a partir do nível mais alto em projeção horizontal. Entretanto, não foi apresentado mapa com a localização das APP's do reservatório, nem foi apresentada uma estimativa da área do entorno do reservatório considerada como sendo de preservação permanente. Ressalta-se que, como até o presente momento o reservatório não atingiu a sua cota máxima, em muitos locais a APP do mesmo se encontra a dezenas, às vezes centenas de metros do nível atual do lago, sendo comum a ocupação da mesma e mesmo da área inundável do reservatório.

Área de Proteção Ambiental Pouso Alto - criada pelo Decreto Estadual nº 5.419 de 07/05/2001. A APA engloba áreas dos municípios de Alto Paraíso de Goiás, Cavalcante, São João d'Aliança, Colinas do Sul e Teresina de Goiás. Possui área de 872.000ha e se localiza na região leste do reservatório. Foi apresentado mapa com a localização da mesma.

Terra Indígena Avá - Canoeiro - criada pela Portaria Ministerial nº 598 de 02/10/1996. Possui área de 38.000ha e se localiza a leste do reservatório, englobando terras dos municípios de Minaçu e Colinas do Sul. Foi apresentado mapa com a localização da mesma.

Parque Nacional da Chapada dos Veadeiros - criado pelo Decreto n ${ }^{\circ}$ 70.492/1972. Engloba terras dos municípios de Alto Paraíso e Cavalcante e possui uma área de 171.924,54ha. Segundo as informações prestadas, a AID do reservatório não atinge a zona de amortecimento do parque. Entretanto, na imagem $l$ apresentada só está plotada a zona de amortecimento do Parque Nacional da Chapada dos Veadeiros, não mostrando a relação entre a AID e a Ali do reservatório com o mesmo.

Áreas Prioritárias para Conservação - essas áreas foram identificadas através do PROBIO Projeto de Conservação e Utilização Sustentável da Diversidade Biológica Brasileira. Dentre as sete áreas prioritárias para conservação da biodiversidade identificadas, três apresentam importância extremamente alta, uma apresenta importância alta e três apresentam alta importância biológica. Analisando-se o mapa 
apresentado, constata-se que a região leste do reservatório, em direção ao Parque Nacional da Chapada dos Veadeiros e Reserva Indígena Avá Canoeiro, encontra-se quase que toda inserida em áreas de alta a extremamente alta importância para conservação. Não foi informado a extensão das áreas prioritárias para conservação encontradas na região, nem qual extensão das mesmas é diretamente e indiretamente afetada pelo empreendimento.

Reserva Particular do Património Natural - RPPN - Foram identificadas 18 RPPN's, das quais somente 15 foram plotadas, uma vez que as demais não apresentavam coordenadas geográficas. Das RPPN's plotadas, nove se localizam no município de Alto Paraíso de Goiás, principalmente nas imediações do Parque Nacional da Chapada dos Veadeiros, uma no município de Padre Bernardo, uma no município de Trombas, duas no município de Planaltina de Goiás, uma no município de Colinas do Sul, uma no município de São João d'Aliança e uma no município de Cavalcante. Uma vez que os dados estão incompletos, não foi informada a área total protegida na forma de RPPN's.

Parque Natural Municipal Lavapés - criado pelo Decreto Municipal $n^{\circ} 24$, de 22/02/2002. Localizado no município de Cavalcante, possui área total de 339ha. Segundo informações prestadas, o mesmo não possui uma base georreferenciada, de modo que não pode ser plotado em mapa.

\subsection{Plano de Monitoramento do Lençol Freático}

O principal objetivo do programa é o monitoramento do aquífero freático na AID e do seu entorno imediato nas áreas susceptíveis à elevação do nível freático. Áreas previamente identificadas deverão ser monitoradas para apontar medidas preventivas ou servir como subsídio ao planejamento do uso e ocupação do solo.

O programa abrangerá a Área de Influência Direta do empreendimento (que está sendo considerada em princípio como a Área de Preservação Permanente), particularmente os pontos situados em áreas potencialmente vulneráveis a alterações na dinâmica do nível freático decorrentes do enchimento do reservatório até a sua cota máxima. Localmente a AID pode ser aumentada em função da definição de áreas críticas, principalmente nas vizinhanças de cidades, vilas, aglomerações populacionais e dolinas.

Segundo o Plano, foram identificados três domínios hidrológicos: Rochas Cristalinas, onde ocorrem aquíferos do tipo Fissural (Rochas Cristalinas); Aquíferos Cársticos (associados a rochas calcárias) e sistemas de Aquíferos das Coberturas Detrito Lateríticas de Idades Terciárias e Quaternárias. Embora esta classificação não esteja incorreta, ressalta-se que foi lançado em 2006 
o estudo sobre a Hidrogeologia do Estado de Goiás, onde se identificou três sistemas aquíferos freáticos, equivalentes ao Aquífero das Coberturas Detrito Lateríticas de Idades Terciárias e Quaternárias, e oito sistemas aquíferos profundos, dos quais sete correspondem ao aquífero do tipo Fissural e um ao Aquífero Cárstico, na região do lago da UME Serra dk Mesa.

Na formação de lagos artificiais, a elevação e o rebaixamento do nível das águas promovem uma nova pressão que atua sobre as nascentes, que consequentemente leva a uma subida generalizada do nível das águas subterrâneas para uma nova posição. Este fenómeno é acompanhado por uma inversão temporária do fluxo subterrâneo, até a nova posição de equilíbrio seja estabelecida e o fluxo retorne em direção ao rio.

Poços rasos e profundos, nascentes, dolinas, áreas pantanosas e outras feições localizadas no entorno do reservatório poderão ser beneficiados ou prejudicados com a recarga induzida através de fraturas ou do manto de intemperismo. A alteração do lençol freático pode criar novas nascentes e promover o aparecimento de lagos nas cercanias do reservatório.

O programa será realizado em três etapas:

Primeira Etapa - com coleta de dados básicos disponíveis; levantamentos das informações cadastrais referentes à infra-estrutura dos proprietários atingidos (fontes, nascentes, poços rasos e profundos); interpretação fotogeológica na escala 1:25.000 visando a identificação e definição de áreas críticas; preparação de plantas - base e mapas orientativos para trabalhos de campo.

Segunda Etapa - viagem ao campo para reconhecimento e seleção de áreas críticas; verificação da cota do nível d'água atual e a cota da boca em superfície em locais onde se identificarem dolinas; localização das áreas críticas para instalação de medidores de nível d'água; análise e interpretação dos dados coletados; elaboração de planilhas para utilização nas campanhas de monitoramento do nível d'água.

Terceira Etapa - caracterização hidrogeológica a partir dos estudos geo-hidrodinâmicos dos terrenos; estimativa das modificações que poderão ser induzida ${ }^{\wedge}$ pelo reservatório considerando as análises de recarga natural dos aquíferos; monitoramento hidrogeológico sistemático mensal; análises físico-químicas e bacteriológicas nas águas dos poços ou outras feições atingidas, se for o caso; e elaboração de relatórios.

A metodologia apresentada foi considerada adequada ao monitoramento hidrogeológico da AID do Reservatório de Serra da Mesa. Entretanto, solicita que relatórios com os resultados de cada etapa sejam encaminhados ao IBAMA para acompanhamento. Ao final da segunda etapa será imprescindível o encaminhamento de mapa com localização das áreas críticas bem como dos 
medidores de nível d'água. No caso específico do monitoramento previsto na terceira etapa, deverão ser apresentados relatórios trimestrais.

Num primeiro momento, deverão ser escolhidos poços ou outras feições atingidas e realizadas análises físico-químicas e bacteriológicas para verificação de uma possível contaminação devido à elevação do lençol freático. As análises deverão ser realizadas num período mínimo de um ano. Após avaliação dos dados por parte da equipe técnica do IBAMA, será verificada a necessidade de manutenção ou não desse monitoramento. Os resultados das análises deverão ser encaminhados juntamente com o resultado do monitoramento do nível d'água.

Uma vez que está previsto que o enchimento do reservatório da UHE Serra da Mesa já ocorra no ano de 2011, os trabalhos deverão ser iniciados imediatamente.

\section{3 - Conclusão e Recomendações}

1. Detalhar a amostragem de ictiofauna para obtenção da licença de monitoramento;

2. Deverá ser providenciado o desmatamento de modo a proporcionar o aproveitamento do material lenhoso que será submerso;

3. Propor o envio do plano de desmate conforme a previsão de enchimento do reservatório, priorizando as áreas que serão submersas primeiro;

4. No Plano de Monitoramento de Mercúrio, sugere-se que seja analisada a possibilidade de se coletar amostras de sedimento na região dos pontos BGG08 e MRN30;

5. Iniciar o Plano de Comunicação Social e Educação Ambiental com 30 dias de antecedência ao início da elevação do nível do reservatório. Caso a previsão para enchimento acima dos 60\% da capacidade máxima já esteja numa data inferior aos 30 dias, iniciar o plano imediatamente;

6. Apresentar mapa com a localização das APP's do reservatório e uma estimativa da área do entorno do reservatório considerada como sendo de preservação permanente;

7. Informar a extensão das áreas prioritárias para conservação encontradas na região e qual extensão das mesmas é diretamente e indiretamente afetada pelo empreendimento;

8. Apresentar, em imagem, a interferência da AID e Ali do reservatório com a zona de amortecimento do mesmo. 
Ana Carolina Bonifácio da Silva

Analista Ambiental

\section{Eduardo da Costa de Assis}

Analista Ambiental
Dilemando Honório

Analista Ambiental
Luciana Miyahara Teixeira

Analista Ambiental

\section{Ruimar Bernardo da Silva}

Analista Ambiental 
ANEXO D - Autos de Infrações Lavrados no Ano 2009

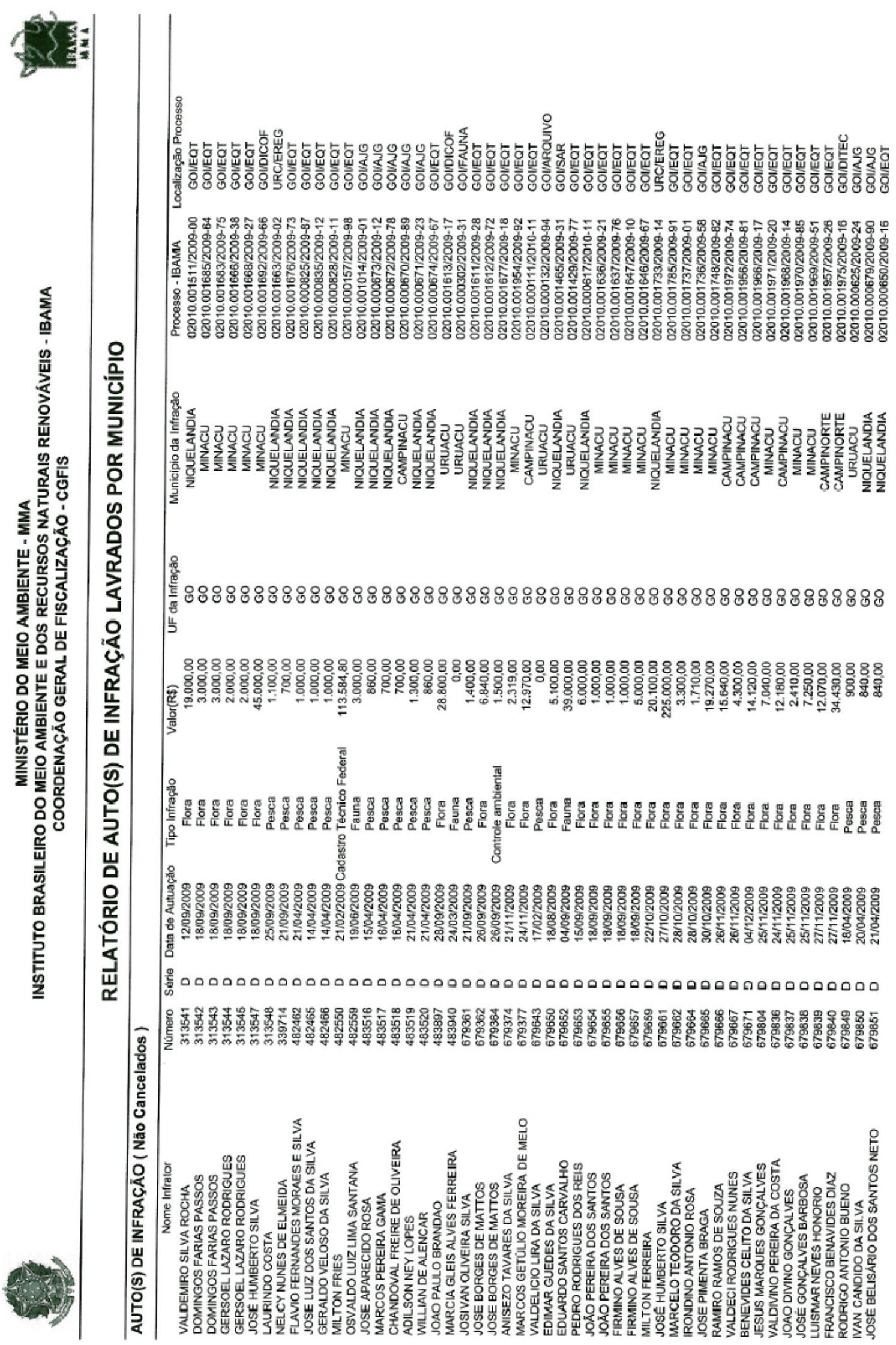


ANEXO D continuação- Autos de Infrações Lavrados no Ano 2009

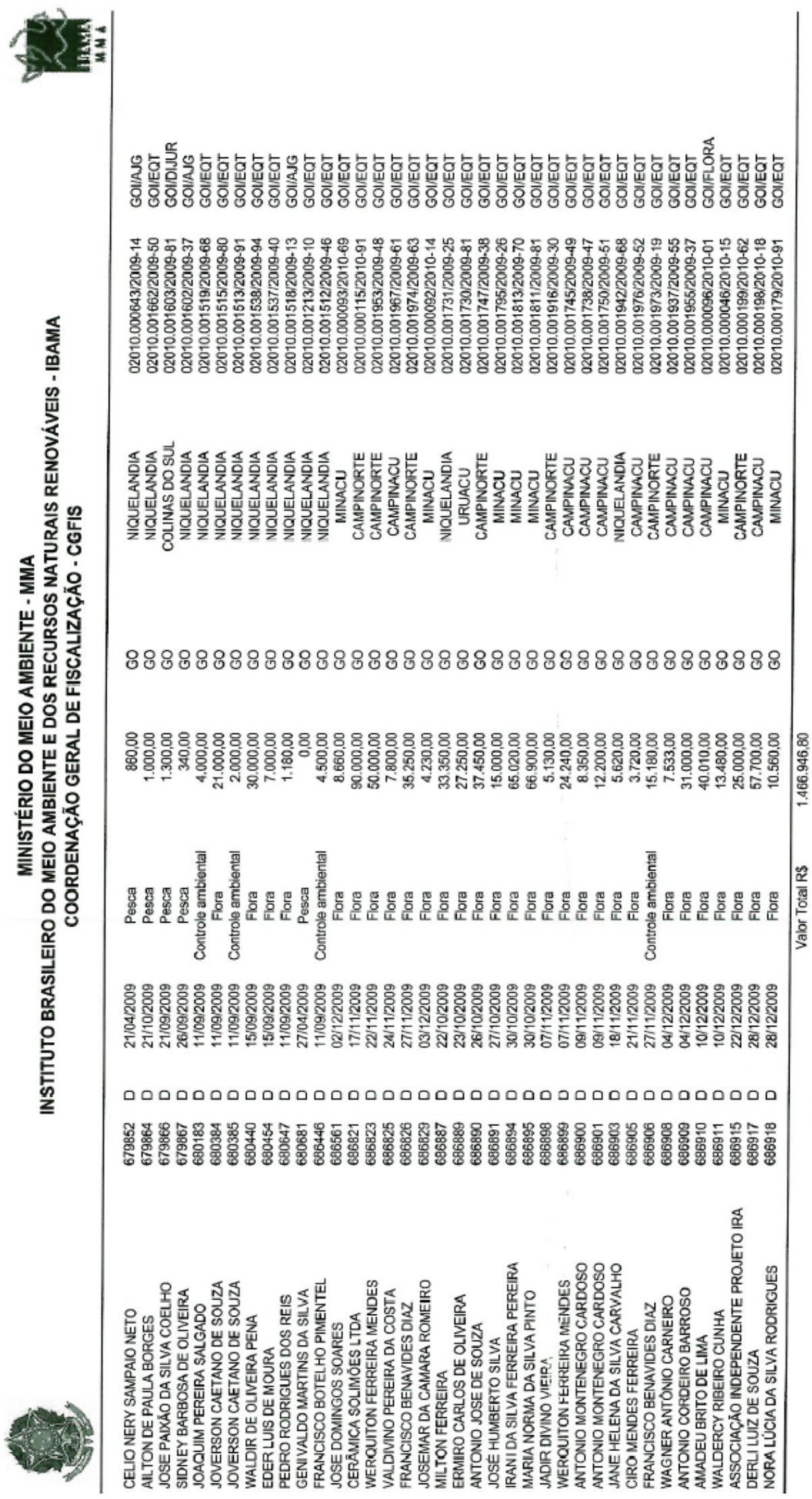


ANEXO E - Autos de Infrações Lavrados no Ano de 2010

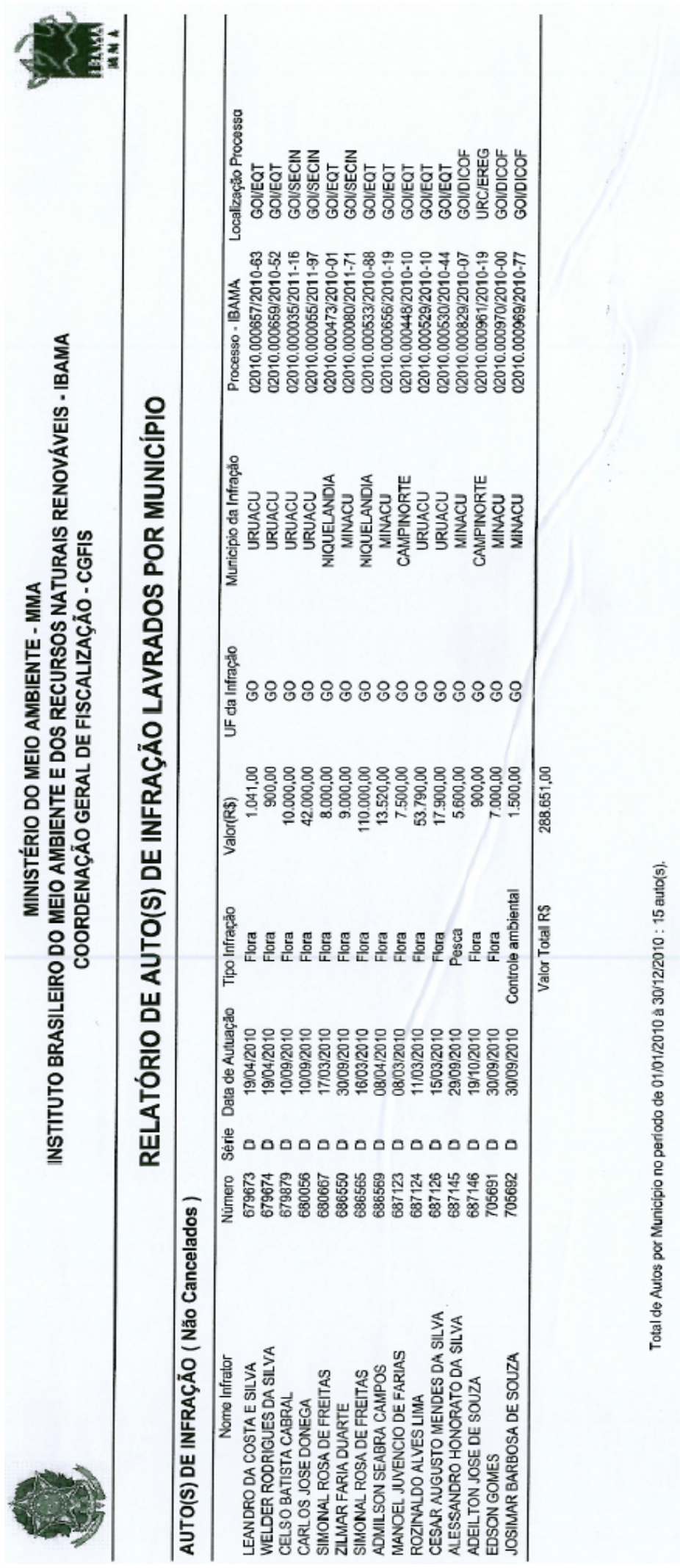

